\title{
A Systematic Mapping of Accessibility Problems Encountered on Websites and Mobile Apps: A Comparison Between Automated Tests, Manual Inspections and User Evaluations
}

\author{
Delvani Antônio Mateus (D) [ Universidade Federal de Lavras|delvanemateus91@gmail.com ] \\ Carlos Alberto Silva (D) [ Universidade Federal de Lavras |carlos.silva.10@outlook.com ] \\ Arthur F. B. A. de Oliveira (D) [ Universidade de São Paulo | atroliveira92@gmail.com ] \\ Heitor Costa (D) [ Universidade Federal de Lavras | heitor@dcc.ufla.br ] \\ André Pimenta Freire (D) [ Universidade Federal de Lavras $\mid$ apfreire@dcc.ufla.br ]
}

\begin{abstract}
The use of websites and mobile applications has become essential for numerous daily activities. However, not everyone can have full access to such services and content due to many websites and applications being inaccessible to people with disabilities, such as people with vision impairments. In this context, even though developers may demonstrate an effort to create more accessible content, there is limited information about the characteristics of different accessibility assessment methods applied to websites and mobile applications. Thus, the present study aimed to perform a meta-analysis of 38 types of accessibility problems on websites and mobile applications extracted from 38 studies in the literature from an initial search of 304 articles. Studies carried out automated assessments using tools, expert-based inspections and user testing involving disabled people. The results confirm other considerations made in the literature, showing that automated evaluation methods have significant limitations on an adequate coverage of accessibility problems, covering less than $40 \%$ of the types of problems found on websites and less than $20 \%$ on mobile apps. A significant percentage of problems both on mobile and web platforms were only encountered by studies involving users. Expert inspection showed a higher coverage of problems encountered by users, both on mobile apps and on websites, despite not covering all of them. Thus, the article concludes by showing a consolidation of literature data to reinforce that effective accessibility evaluations of web and mobile applications should count in expert-based inspections and user tests involving people with disabilities.
\end{abstract}

Keywords: Web Accessibility, Mobile Accessibility, Evaluation Methods, Systematic Mapping.

\section{Introduction}

With the popularization of digital resources, several companies from different sectors started to offer digital services such as e-commerce, communication, bank transactions, geolocation, and social networks. Using the web and mobile platforms, people have gained greater mobility to carry out their daily tasks. However, not everyone can use these features. Not all mobile and web apps have accessibility features, making people with disabilities unable to use these apps to take advantage of all the features. In this context, people with visual impairments have encountered several accessibility barriers. The World Wide Web Consortium (W3C) defines web accessibility as "the possibility and the condition of reach, perception, and understanding for the use, in equal opportunities, with security and autonomy, of sites and services available on the web" (W3C, 2016). We can also expand that concept to the context of the mobile app.

Usability and accessibility are fundamental requirements for any software to be high quality, whether a website or an application. According to the ISO 9241-171 standard (ISO, 2018), accessibility is the "usability of a product, service, environment or installation by people with the widest range of resources". Besides, that standard defines usability as "the extent to which a system, product or service can be used by specific users to reach specific objectives with effectiveness, efficiency, and satisfaction in a specific context of use".

Providing accessible interaction is fundamental to users with disabilities. Accessible websites and mobile apps should provide usable interaction for all users, including those with different sensory and motor abilities and users of computers with assistive technologies. Designers and developers need to count on appropriate techniques to design and evaluate the accessibility of accessible technology. Appropriate techniques are essential to learn user needs and uncover accessibility problems during the development process. Considering the aim of technology managers and developers to reach as many users as possible, knowing the main advantages and disadvantages of different evaluation methods is essential to plan their development process.

The literature on Human-Computer Interaction presents different methods to evaluate accessibility to reveal problems for people with disabilities, including people with visual impairments. Practitioners can employ accessibility evaluations through tests with users, manual inspections by specialists, and automated tests. However, more research is needed to understand the trade-off of using different methods for assessing web and mobile accessibility, focusing on visually impaired users. There is still limited knowledge on the coverage of the methods on the different types of accessibility problems encountered by people with visual impairments in these systems (Stephanidis, 2009).

In our previous study (Silva et al., 2019), we conducted a systematic literature mapping covering 19 studies that performed evaluations of web accessibility. We analyzed 38 types of accessibility problems and compared the types of 
problems covered by automated tools, manual inspections, and user evaluations. However, the study did not cover the problems encountered in mobile applications. Therefore, in the context of web and mobile accessibility for visually impaired users, this study aimed to compare different types of problems found in different ways of assessing accessibility in the literature by exposing benefits and disadvantages. Thus, we proposed the following main research question:

When performing automated assessments, inspections by experts, and tests with users in web and mobile applications focusing on people with visual impairments, what are problems identified?

We defined the following specific questions to answer the research question:

RQ1: Among the problems identified in accessibility evaluations, what are problems found by any combinations of methods?

RQ2: What are the benefits and limitations of each method for evaluating accessibility on the web?

RQ3: What are the benefits and limitations of each method for evaluating accessibility on mobile platforms?

The remainder of this article is organized as follows. Section 2 presents web and mobile accessibility concepts, methods for finding accessibility problems, and related work. Section 3 describes the methodology used to conduct the study. Section 4 presents the results obtained with the analysis of the studies selected from the literature. Section 5 discusses the advantages and limitations of the evaluation methods to assess web and mobile accessibility. Section 6 presents the final remarks.

\section{Background and related work}

This section presents the main concepts of web and mobile accessibility, accessibility evaluation methods, and related work.

\subsection{Web and mobile accessibility}

Like everyone else, users with disabilities use the web and mobile applications for a variety of activities. For that use to occur with autonomy, blind or low vision people use screen reader software - an assistive technology that allows adequate access to systems using means non-visual, mainly with speech synthesis (Stephanidis, 2009) or use content expansion features. So, we can understand assistive technology as "hardware or software added or incorporated into a system that increases accessibility for an individual" (ISO, 2018). This technology brings more accessibility for people with different needs.

Although assistive technologies can provide more autonomy for people with disabilities, people with different types of disabilities (e.g., visual impairment) cannot have complete autonomy when accessing web pages or mobile applications with accessibility issues. In this context, web accessibility "deals with the possibility and the condition of reach, perception, and understanding for use, on equal terms opportunities, with security and autonomy, of websites and services available on the web" (W3C, 2019). Therefore, accessibility deals with the digital environments that facilitate interaction, information access, and manipulation by people with disabilities.

People with visual impairment can use different types of assistive technologies to use the web and mobile applications. On desktop computers and smartphones, people with little or no residual visual typically use screen reader software. That software synthesizes the content presented on the screen once developers provide appropriate textual descriptions and semantic information. On the one hand, blind people commonly use the keyboard to interact with the screen on desktop computers; on the other hand, those people use special gestures on touch screens as commands on mobile devices. People with low vision use different adaptations and specialized software to enlarge content, change colour schemes and enhance the display.

\subsection{Accessibility evaluation}

We can find different evaluation methods in the literature to encounter accessibility problems in websites and mobile applications. Most methods are concerned with evaluations with users with disabilities or inspections that involve reviewing accessibility guidelines. These methods usually involve the following characteristics (Brajnik, 2008):

- To prescribe which steps, decisions, criteria should be used and what conditions accessibility problems are detected;

- To prescribe how to classify and indicate problem ratings (in terms of severity, priority, and vice-versa);

- To prescribe how to aggregate, describe, and report data on accessibility;

- To prescribe how to select web pages or screens for evaluation.

The main accessibility approaches typically used to evaluate the web and mobile devices accessibility are automated evaluations, manual inspections by experts, and user evaluation.

\subsubsection{Automated evaluation}

The automated evaluation involves an evaluator using an automatic accessibility assessment tool to evaluate the compliance of a web page or the mobile application screens concerning accessibility recommendations coded in the tool (Brajnik et al., 2011). The resources available in automated tools can help verify a subset of guides such as the WCAG (Web Content Accessibility Guidelines) in a less time-consuming way that professionals use (Ivory, 2013). Those tools can be useful to help evaluate accessibility problems that would be tedious to manually check, for example, the lack of features like alternative texts and headings and values of colour contrasts predefined by sets of guidelines (Freire, 2012). Despite its 
benefits, the automated evaluation is limited and does not can identify all web accessibility issues. For example, a tool can determine whether there is an alternative text in an image but cannot judge whether the text is presented appropriately to the context (Brajnik et al., 2011).

\subsubsection{Inspection by specialists}

Along with the automated evaluation, checking accessibility manually by experts has a relevant role to be applied together in the evaluating process of web applications (Brajnik, 2008; Freire, 2012). The most used inspection by specialists is the Conformity Assessment. In this method, the evaluator uses guides such as the WCAG (W3C, 2020), Section 508 (Jaeger, 2006), and e-MAG (Electronic Government Accessibility Model) (Governo Brasileiro, 2014) to assess whether a web page complies with the accessibility recommendations in those guides (Brajnik et al., 2011; Abou-Zahra, 2008). The inspection by specialists finds problems on mobile and web platforms that cannot be verified automatically. Despite not identifying all possible problems encountered by users, it is a way to reveal them in earlier development stages (Freire, 2012; Zaphiris, 2007).

\subsubsection{Tests with users}

In the user tests, the goal is to involve (disabled) users in verifying the accessibility on Web pages. Disabled users are individually invited to browse web pages attempting to perform a task, and their behaviour is observed by the evaluators (Brajnik et al., 2011).

Evaluation with disabled users is critical because accessibility evidence (or lack thereof) of a web page or mobile application in its actual use by the target audience is provided. However, recruiting users with different types of disabilities is not an easy task (Petrie and Bevan, 2009).

\subsection{Related work}

In the literature, we found studies whose aim is to use accessibility assessment methods to understand the problems present on Web sites and mobile applications, their compliance with the existing accessibility guidelines, and the relationship among problems found by different methods.

Harrison and Petrie (2007) used assessment methods with users and experts to assign degrees of priority for accessibility and usability problems and compared them with the degrees of priorities proposed by the WCAG 1.0 guides for accessibility and Health and Human Services for usability (Harrison and Petrie, 2007). The researchers selected six eCommerce and e-government websites, evaluated by six users with different disabilities and one specialist. They concluded that the severity attributed to users and the specialist was similar. However, they differed from the guide's severity ratings, which proved to be a problem. A developer, while using the guides, is concerned with prioritizing the most critical problems. The research concluded that the experts perform better in foretelling the severity attributed by users than the priorities defined by the guidelines.
Regarding the automated tools used in Vigo et al. (2013)'s study, the objective was to understand the effectiveness of those tools for analyzing web accessibility concerning the WCAG 2.0 guidelines. These authors carried out an empirical evaluation of three Web sites and used six different tools. The authors compared the results with the authors' manual inspection with the guide WCAG 2.0 on the same websites. They concluded that relying only upon automated tools is not the best option since they covered from $23 \%$ to $50 \%$ of the authors' total success through the guide. Besides, each tool found, on average, 4 to 10 success criteria with the possibility of false positives.

In Jaeger (2006)'s study, the authors understood how accessible the US government websites were to the Section 508 accessibility guide. They pointed out the importance of involving users in the testing websites process. They also stressed the experts' importance to ensuring accessibility in the development and maintenance and the role of the automated tools to support the testing process (but not as the sole means for evaluation). Finally, their study pointed out the importance of improving feedback channels to understand the difficulties that disabled people can have with the site. For this purpose, ten government websites were evaluated through a set of methods, which are: i) analysis to understand whether the Section 508 standards attendance would result in a website accessible; ii) expert inspection to understand whether the Web sites met Section 508 standards; iii) tests with users to provide a detailed picture from the users' perspective with visual and motor disabilities; iv) automated tests to assess whether they are capable of providing a problems overview, and v) one questionnaire with webmasters to understand when deciding to implement the Section 508 standards and what types of evaluations carried out on the websites. In conclusion, the study provided some guidance for government agencies to meet the Section 508 standards requirements.

To investigate accessibility barriers in mobile applications, da Silva et al. (2018a)'s study found gaps in WCAG 2.0 technical guidelines, making them insufficient to meet all the disabilities users' needs. The work involved the Mercado Livre application, a mobile system aimed at electronic commerce, where the interaction of five visually impaired people was observed. All users involved in the study used a screen reader. They were asked to perform some tasks. Except for only one participant, the others had a residual view, but it did not enable them to use other resources to interact with mobile applications, such as expanding content. After completing the tasks, a questionnaire was applied to the participants to remember their thoughts during the task execution. Thus, this process characterizes the retrospective verbalization protocol (da Silva et al., 2018a). As a study result, the authors presented several difficulties reported by users on the interaction with the selected application and violations related to the WCAG 2.0 guidelines. For example, the application had icons with alternative text that did not adequately describe the features, violating one of the WCAG 2.0 guidelines.

Another study examining mobile accessibility was performed by Carvalho et al. (Carvalho and Freire, 2017; Carvalho et al., 2018a). In those studies, the authors investigated the interface components adequacy when developing mobile 
systems. The research involved analyzing three prototypes of mobile systems, focusing on accessibility problems for visually impaired people. They performed an accessibility assessment on a sample of thirty Android interface components. The components selection was based on documents investigating the standard components related to the HTML and the Android system. Based on the WCAG 2.0 success criteria, an expert appraiser audited all of the sample interface components present in the three prototypes in that study. The prototypes were implemented using three methods. The first included standard Android Studio components, generating a native application; the second prototype was developed using HTML components, resulting in a system with web resources; and the third was a hybrid application.

As a result, web applications proved to be more accessible when using TalkBack, but more complex web components, such as audio and video, violated some WCAG 2.0 success criteria. For example, the authors recommended that developers choose apps with web resources or hybrid applications where the content is divided into several sections. The study results show that they are superior concerning the native application without web resources (Carvalho and Freire, 2017).

da Silva et al. (2016a) also conducted an empirical study focused on mobile systems, aiming to identify accessibility barriers in the WhatsApp application. The barriers were related to the WCAG 2.0 success criteria. Their study involved five blind users who were asked to perform some tasks and verbalise their interaction experiences later. Users performed eleven tasks on WhatsApp, and the interaction with the application allowed researchers to observe existing accessibility barriers. As an example, when performing the tasks, there was a feedback absence and buttons without labels. Besides, most of the tasks were completed by users, but researchers had to help in some situations. Accessibility barriers were grouped according to the WCAG 2.0 principles, where researchers noticed guideline violations in almost all principles, except for the robust principle.

Ghidini et al. (2016)'s study assessed the types of interaction facilitates used in mobile systems by visually impaired people. The study involved the electronic agenda prototype development and tests with participants. Interviews were conducted with six visually impaired people to understand the most common interacting means with smartphones and the facilities and barriers encountered in this interaction. Concerning the interaction with that application, the authors identified positive aspects and functionalities that can improve usability. With the results obtained from the interviewees, they developed a prototype to obtain other results, replacing the native calendar. After creating the prototype, the researchers conducted tests with users, which involved the native calendar application and the prototype. The study was composed of tasks in both applications and involved four visually impaired users who used screen readers in that testing. Next, the participants were asked about their interaction with the two applications. Regarding the native calendar, the authors state that the participants' general opinion was that it had poor usability. On the other hand, when asked about the interaction with the researchers' prototype, the participants considered it easier to use. Considering the results obtained, the researchers applied changes to the developed prototype, but they did not observe all the users. In making these changes, the researchers performed another test with a user with low vision. As in the test carried out previously, the study involved the native application and the researchers' prototype. In the native application, at various times, the researchers noticed that the participant had difficulty finding what looking for, such as buttons. Unlike the test with the native application, the prototype results were better.

Hanson and Richards (2013) investigated accessibility indicators on the web on a wide range of websites. Conducted for fourteen years, the authors sought to observe improvements in accessibility and possible reasons that caused changes related to web accessibility. The study involved one hundred and eight sites, analyzing whether they complied with WCAG 2.0 recommendations using automated inspections. Before the WCAG 2.0 guidelines launch, the researchers noted the application and impacts caused by the WCAG 1.0 recommendations. As a criterion for selecting the sites to be tested, the researchers included only sites from English-speaking countries with a web accessibility policy. It facilitated the sites' understanding and the developers' intentions. Considering the researchers' analyses, there was low adherence to the WCAG 2.0 guidelines in many cases. According to them, the developers' lack of knowledge is one factor that causes low adherence. Besides, the complexity of the guidelines makes it difficult for developers to understand, often not experts in web accessibility, resulting in the lack of necessary resources implementation. However, the study also pointed out that the web has become more accessible in the last years, as there are fewer violations related to alternative means for images, greater headers use, among other changes. The researchers concluded that improvements in web accessibility result from good coding practices, the desire to improve the design, and the search for better results in web searches.

Rømen and Svanæs (2012)'s study involved desktop technology, where empirical tests were performed to verify the coverage level of WCAG 1.0 and WCAG 2.0 standards. The study involved three visually impaired people, two users with dyslexia, two motor disabilities, and six people without disabilities. Two sites in Norway were inspected in the survey, based on identical tasks, since the two platforms web content was similar. The study results showed that, on average, people without disabilities identified fewer problems compared to disabled users. The study also showed that referring to the WCAG 1.0 standard, less than $42 \%$ of the identified barriers would be covered by the technical guidelines. Concerning the WCAG 2.0 standard, less than $49 \%$ of accessibility problems would be covered.

It is also important to highlight Power et al.'s study (Power et al., 2012, 2011), in which the authors investigated web accessibility problems involving desktop technology. Thirtytwo visually impaired users performed some tasks and sixteen sites based on the WCAG 2.0 success criteria. The results of this study showed that: i) WCAG 2.0 technical guidelines covered only $50.4 \%$ of the problems identified by users; ii) many developers do not usually implement websites following technical guidelines, and iii) there is little evidence of a decrease in the number of accessibility problems when web systems are developed based on WCAG 2.0. The study also presented the problems' severity, the average number of prob- 
lems found on each evaluated site, and accessibility barriers categorization.

The analysis of related studies reported in this section showed that many studies in the literature had investigated accessibility problems encountered by different evaluation methods on websites and mobile applications. In web applications, more studies delved into the coverage analysis of different methods. However, there are fewer such studies focused on mobile accessibility. Finally, it is worth noting that most of the analyses were performed on single datasets derived from individual studies. Hence, the present paper analysis enabled a deeper meta-analysis of different evaluation methods results from various studies in the literature, focused both on web and mobile platforms.

\section{Methodology}

This study carried out a comparative analysis among different accessibility problems encountered in web and mobile applications reported in literature focused on visual disabilities people. Thus, the results allow practitioners and researchers to know more about accessibility evaluations in web and mobile platforms since the study brings benefits and limitations to each method. Developers and appraisers can understand how to combine the different techniques in the evaluation processes.

For this purpose, the study encompassed a systematic literature mapping in the last seven years, looking for problems found by different evaluation methods - automated tests, expert inspections, and tests with users.

\subsection{Search strategy}

The following search string was designed to find studies in which some accessibility assessment was applied on the web or mobile applications, using automated tests, user tests, and expert inspections:

TITLE-ABS-KEY ( ( accessibility OR accessible ) AND ( mobile OR android OR apps OR ios OR talkback OR "talk back" OR "voice over" OR voiceover OR web OR website OR "web site") AND ("visual impairment" OR blind OR blindness OR "visual disability" OR "low vision" OR "partially sighted") AND ( evaluation OR assessment OR testing OR test OR inspection OR audit) AND ( specialist OR expert OR appraiser OR estimator OR evaluator OR assayer OR manual OR automatic OR automated OR tool OR tools OR user OR users ) ) AND ( LIMIT-TO ( PUBYEAR, 2020 ) OR LIMIT-TO ( PUBYEAR, 2019) OR LIMIT-TO ( PUBYEAR , 2018 ) OR LIMIT-TO ( PUBYEAR, 2017 ) OR LIMIT-TO ( PUBYEAR , 2016 ) OR LIMIT-TO ( PUBYEAR, 2015 ) OR LIMIT-TO ( PUBYEAR, 2014 ) )

This string was used in the scientific article repository Scopus, which contains the most relevant Computer Science and Human-Computer Interaction publications. 267 studies were found with that string, and the search was performed from November 14, 2020 to June 13, 2021.

\subsection{Inclusion and Exclusion Criteria}

For including the studies in the systematic literature mapping, the following inclusion criteria were defined:

- Studies should report assessing the accessibility of Web sites or mobile applications using automated tests, inspections by experts or user tests;

- Studies should focus or address evaluations targeted at visually impaired users;

- Studies must explicitly report the types of accessibility problems encountered;

- The studies' full text must be available through the Brazilian Capes Portal;

- Studies should report in detail the methods used and the procedures for evaluation;

- Studies must be published up to February 2021.

In addition, the following exclusion criteria were defined:

- Short paper studies with non-detailed presentation of methods used;

- Studies that only report the number of problems encountered, without qualifying the types of problems.

- Articles not written in English or Portuguese.

\subsection{Study Selection}

Below are the main steps for performing the systematic mapping. The first step was the execution of the search string in the Scopus database. The search returned two hundred sixtyseven potential studies. The second stage consisted of reading the titles, excluding only studies that presented a disparity in the title description, moving 190 studies to the next stage. The third step was to read the abstracts all the abstracts. In this step, we excluded articles that did not present criteria for inclusion, such as evaluation methods, barriers encountered. In the third stage, the remaining 108 studies were read entirely, following the inclusion criteria. Each article read was extracted from data. Seventy studies were discarded as they did not present accessibility problems identified by some evaluation method. Two studies were also discarded after repeatedly checking the publisher server for problems to obtain the full text.

Thus, the final selection resulted in 38 studies. However, some assessed web or mobile accessibility used one or more different methods among the selected studies. Table 1 presents all the studies selected in the complete reading phase.

The entire process of analyzing the studies and extracting the data happened manually, no tools were used.

- Step 1: The selected database was searched using a previously defined search string. From this, 267 potential studies were found. All titles, 190 studies with potential for systematic mapping were selected for the next step (Step 2), according to the application of the inclusion and exclusion criteria.

- Step 2: Of the 190 studies identified in Step 1, 108 studies were accepted to be analyzed in this stage. The abstracts of these studies were read, again using the inclusion and exclusion criteria; 
- Step 3: In this step, of the 108 consolidated studies of Step 2, 38 studies presented information relevant to the topic. From these studies, data were extracted to answer the research questions. These data were gathered in a spreadsheet to be analyzed.

\subsection{Data extraction}

After selecting the studies, the data were extracted from analyzed and consolidated. The following data were extracted from each study:

- Instances of accessibility problems encountered;

- Type of method used to find each problem;

- Automated tool used;

- Number of pages and evaluated;

- Number of applications evaluated;

- Specialists' profile involved in manual inspections;

- Browser used in evaluations;

- Mobile operating system;

- Screen readers used in the evaluations;

- Users' profile who participated in the evaluations;

- Used smartphones.

We carried out an analysis to consolidate the types of methods used and the types of problems encountered from the data extraction. An analysis of types of problems and a unique category is assigned to the types of problems to make it possible to compare the types of problems encountered by the different methods.

\section{Results}

This section presents the results obtained in the mapping study. We present the accessibility evaluation methods examined and accessibility problems identified. Data identified by the three main methods are shown separately. Similarly, we also summarized the methodological approach used and their characteristics. For example, we discussed the tools involved and the participants' profiles in user studies. Besides, accessibility problems are made explicit, relating them to the studies that identified them. Some accessibility problems were identified by more than one study. Even when it comes to a single evaluation method, there are also problems with accessibility identified by one study only, and there are accessibility issues found on the web and mobile platforms.

\subsection{Automated Evaluation}

This section presents the results obtained with the analysis of nine studies that carried out automated accessibility evaluations.

\subsubsection{Automated Web Evaluation}

Altogether seven studies involved automated testing on the web, with a set of twelve tools. Table 2 presents the tools used, the number of tools, the number of evaluated sites. The Wave tool was used in three studies. Three studies performed the tests with more than one tool, although one of the studies did not explain which tools were used.

The problems found by such studies had a total of twenty barriers, with violations related to the absence of labels, lack of headers, absence of alternative text, empty links, and duplicate information. Table 10 (in the Appendix) shows all the accessibility problems they encountered and the number of studies they found.

\subsubsection{Automated Evaluation of Mobile Apps}

Two studies involved automated tests on the mobile platform with a set of three tools. Table 3 presents the tools used, the number of tools, the number of apps evaluated, only one study used more than one tool. All were performed with the Android system.

The problems encountered by these studies had eleven barriers, with related violations: Inappropriate description in controls, target size, insufficient contrast, spacing and inappropriate title, among others. Table 11 (in the Appendix) shows all the accessibility problems they found and the number of studies they found.

\subsubsection{Common Problems}

Some violations were the same for both platforms: absence of labels, inadequate description of controls, duplicate information, insufficient contrast, incompatibility of inappropriate technologies, navigation sequence, visible focus, and spacing. A total of nine types of problems were found in both mobile apps and web apps.

\subsection{Inspection by Experts}

This section presents the results from the analysis of thirteen studies, in which inspections and specialists made the accessibility evaluation.

\subsubsection{Inspection by Experts on Web}

Of the ten studies that performed inspections by experts, six employed three or more experts. Only three studies provided the number and name of the tools used to aid in the inspections. Table 4 shows characteristics related to the methodology used by these studies, explaining the data regarding the method used, including the number of sites, expert profile, number of experts the number of tools involved.

The studies involving expert inspections yielded thirty-five barriers. Table 12 (in the Appendix) lists the types of accessibility problems (or barriers) identified in the studies, such as inappropriate description in controls, visible focus, too much information, useless elements, insufficient contrast, content inaccessible to keyboard interaction, sensory characteristics, and others.

\subsubsection{Inspection by Experts on Mobile Applications}

Of the two studies that performed expert inspections, all used three or more evaluators. The two studies employed the screen reader Talkback. Table 5 shows characteristics related to the methodology used by these studies, explaining the data 
Table 1. List of papers

\begin{tabular}{|c|c|c|}
\hline ID & Title & Citation \\
\hline A1 & $\begin{array}{l}\text { Accessibility and usability of websites intended for people with disabilities: A preliminary } \\
\text { study }\end{array}$ & (Zitkus et al., 2016) \\
\hline A2 & $\begin{array}{l}\text { Accessibility and usability problems encountered on websites and applications in mobile } \\
\text { devices by blind and normal-vision }\end{array}$ & (Carvalho et al., 2018b) \\
\hline A3 & $\begin{array}{l}\text { Analysis of web accessibility in social networking services through blind users' perspec- } \\
\text { tive and an accessible prototype }\end{array}$ & (Loureiro et al., 2014) \\
\hline A4 & $\begin{array}{l}\text { Analysis, redesign and validation of accessibility resources applied to an official electronic } \\
\text { journal for the promotion of equal access to public acts }\end{array}$ & (Rodrigues and Prietch, 2018) \\
\hline A5 & Are users the gold standard for accessibility evaluation? & (Aizpurua et al., 2014) \\
\hline A6 & Correlating navigation barriers on web 2.0 with accessibility guidelines & (Pereira and Archambault, 2018) \\
\hline A7 & Documenting the accessibility of 100 US bank and finance websites & (Wentz et al., 2019) \\
\hline A8 & EBSCO information services usability study on accessibility & (Power, 2018) \\
\hline A9 & Evaluating Responsive Web Design's Impact on Blind Users & (Nogueira et al., 2017) \\
\hline A10 & $\begin{array}{l}\text { Evaluation of e-commerce websites accessibility and usability: an e-commerce platform } \\
\text { analysis with the inclusion of blind users }\end{array}$ & (Gonçalves et al., 2018) \\
\hline A11 & From screen reading to aural glancing: Towards instant access to key page sections & (Gadde and Bolchini, 2014) \\
\hline A12 & How to make an electronic library accessible & (Mátrai, 2018) \\
\hline A13 & $\begin{array}{l}\text { Multi-tool accessibility assessment of government department websites: a case-study } \\
\text { with JKGAD }\end{array}$ & (Ismail et al., 2018) \\
\hline A14 & $\begin{array}{l}\text { Municipal web sites accessibility and usability for blind users: Preliminary results from } \\
\text { a pilot study }\end{array}$ & (Pribeanu et al., 2014) \\
\hline A15 & $\begin{array}{l}\text { Prejudices, memories, expectations and confidence influence experienced accessibility } \\
\text { on the Web }\end{array}$ & (Aizpurua et al., 2015) \\
\hline A16 & Should I trust it when I cannot see it? Credibility assessment for blind web users & Abdolrahmani and Kuber (2016) \\
\hline A17 & Web accessibility in social networking services & (Loureiro et al., 2014) \\
\hline A18 & $\begin{array}{l}\text { Web accessibility of healthcare Web sites of Korean government and public agencies: a } \\
\text { user test for persons with visual impairment }\end{array}$ & $(\mathrm{Yi}, 2020)$ \\
\hline A19 & Web Widgets Barriers for Visually Impaired Users & (Archambault et al., 2017) \\
\hline A20 & $\begin{array}{l}\text { Interdependent components for the development of accessible XUL applications for } \\
\text { screen reader users }\end{array}$ & (Valencia et al., 2014) \\
\hline A21 & Optimus web: Selective delivery of desktop or mobile web pages & (Fernandes et al., 2015) \\
\hline A22 & WhatsApp accessibility from the perspective of visually impaired people & (da Silva et al., 2016b) \\
\hline A23 & $\begin{array}{l}\text { Accessibility of the smart home for users with visual disabilities: An evaluation of open } \\
\text { source mobile applications for home }\end{array}$ & (de Oliveira et al., 2016) \\
\hline A24 & $\begin{array}{l}\text { Accessible smart cities?: Inspecting the accessibility of Brazilian municipalities' mobile } \\
\text { applications }\end{array}$ & (Carvalho et al., 2016) \\
\hline A25 & $\begin{array}{l}\text { Improving the web accessibility of a university library for people with visual disabilities } \\
\text { through a mixed evaluation approach }\end{array}$ & (Galkute et al., 2020) \\
\hline A26 & $\begin{array}{l}\text { Heuristic method of evaluating accessibility of mobile in selected applications for air } \\
\text { quality monitoring }\end{array}$ & (Acosta-Vargas et al., 2019a) \\
\hline A27 & $\begin{array}{l}\text { Accessibility Assessment of Mobile Meteorological Applications for Users with Low } \\
\text { Vision }\end{array}$ & (Acosta-Vargas et al., 2020) \\
\hline A28 & Accessibility evaluation of three important Indian websites & (Mounika et al., 2019) \\
\hline A29 & $\begin{array}{l}\text { Assessing the Accessibility of Library Tools \& Services When You Aren't an Accessi- } \\
\text { bility Expert: Part } 1\end{array}$ & (Rysavy and Michalak, 2020) \\
\hline A30 & A Heuristic Method to Evaluate Web Accessibility for Users with Low Vision & (Acosta-Vargas et al., 2019b) \\
\hline A31 & $\begin{array}{l}\text { Digital equity and accessible MOOCs: Accessibility evaluations of mobile MOOCs for } \\
\text { learners with visual impairments }\end{array}$ & (Park et al., 2019) \\
\hline A32 & Evaluating the accessibility of Kuwaiti e-government websites & (Doush and AlMeraj, 2019) \\
\hline A33 & Mobile Application Accessibility in the Context of Visually Impaired Users & (da Silva et al., 2018b) \\
\hline A34 & Evaluation of tablet PC application interfaces with low vision users: Focusing on usability & (Kulpa and Amaral, 2014) \\
\hline A35 & $\begin{array}{l}\text { The interaction experiences of visually impaired people with assistive technology: A } \\
\text { case study of smartphones }\end{array}$ & (Kim et al., 2016) \\
\hline A36 & $\begin{array}{l}\text { An Empirical Study to Evaluate the Accessibility of Arabic Websites by Low Vision } \\
\text { Users }\end{array}$ & (Akram and Bt Sulaiman, 2020) \\
\hline A37 & $\begin{array}{l}\text { Accessibility of mobile applications: Evaluation by users with visual impairment and by } \\
\text { automated tools }\end{array}$ & (Mateus et al., 2020) \\
\hline A38 & The Current Status of Accessibility in Mobile Apps & (Yan and Ramachandran, 2019) \\
\hline
\end{tabular}


Table 2. Automated tools used in the web studies

\begin{tabular}{|c|c|c|c|}
\hline $\begin{array}{l}\# \quad \text { of } \\
\text { tools }\end{array}$ & Tools used & $\begin{array}{l}\text { \# of sites eval- } \\
\text { uated }\end{array}$ & Study \\
\hline 1 & Wave & 1 & (Zitkus et al., 2016) \\
\hline 1 & SortSite & 1 & (Gonçalves et al., 2018) \\
\hline 6 & $\begin{array}{l}\text { aChecker, } \\
\text { Cynthia Says, } \\
\text { Tenon, Hera, } \\
\text { Wave and } \\
\text { Mauve }\end{array}$ & 33 & (Ismail et al., 2018) \\
\hline 2 & $\begin{array}{l}\text { Wave, W3C } \\
\text { Markup Vali- } \\
\text { dation Service }\end{array}$ & 1 & (Galkute et al., 2020) \\
\hline 4 & $\begin{array}{l}\text { A-tester, Axe } \\
\text { Chrome Plu- } \\
\text { gin, Vamola, } \\
\text { Total11y }\end{array}$ & 3 & (Mounika et al., 2019) \\
\hline 1 & Wave & 1 & (Acosta-Vargas et al., 2019c) \\
\hline 3 & unavailable & 4 & (Loureiro et al., 2014) \\
\hline
\end{tabular}

Table 3. Automated tools used in the mobile studies

\begin{tabular}{|l|l|l|l|l|}
\hline $\begin{array}{l}\text { \# of } \\
\text { tools }\end{array}$ & Tools used & $\begin{array}{l}\text { \# of apps eval- } \\
\text { uated }\end{array}$ & System Smartphone & Study \\
\hline 1 & $\begin{array}{l}\text { IBM Mobile } \\
\text { Accessibility } \\
\text { Checker }\end{array}$ & 479 & Android & (Yan and Ramachandran, 2019) \\
\hline 2 & $\begin{array}{l}\text { Acessibility } \\
\text { Scanner, } \\
\text { MATE }\end{array}$ & 4 & Android & (Mateus et al., 2020) \\
\hline
\end{tabular}

associated with the method used, including the number of applications, the profile of the specialist, number of specialists, the number of tools involved.

The studies involving expert inspections in mobile applications yielded sixteen barriers. Table 13 (in the Appendix) lists the types of accessibility issues identified in the studies, such as visible focus, keyboard inaccessibility, insufficient contrast, images, error identification, and others.

\subsubsection{Common Problems}

Altogether, twelve common problems were found both on the mobile and web platforms: Absence of shortcuts, absence of headers, absence of resources for expansion, lack of labels, absence of alternative text, absence of titles, Insufficient contrast, visible focus, error identification, language not set, keyboard and Inadequate navigation sequence. Even though there are fewer studies on mobile apps, it is worth noting that the same number of problems types were encountered as the web platform.

\subsection{User tests}

This section presents the results encountered by twenty-six studies that conducted tests with users on mobile and web platforms.

\subsubsection{User Tests on Web Sites}

A total of seventeen studies carried out evaluations with blind, low vision, and normal-vision users, ten of these studies used ten or more users, seven used more than one tool, and five did not provide the number and identification of tools. Table 6 presents the characteristics of the methodological approach used in the studies on websites. The table lists the types of sites evaluated, the number of participants and their profiles, and assistive technologies used.

Users encountered issues such as inaccessibility to the keyboard, inappropriate title, inappropriate textual content, inappropriate alternate text, absence of shortcuts, inappropriate feedback, resizing text, images, spacing, and others. The table 14 (in the Appendix) present the accessibility problems identified.

\subsubsection{User Tests on Mobile Platforms}

Of eight studies that performed evaluations with blind users, with low vision, and with normal vision, two of these studies recruited ten or more users, and only two carried out tests in Android and iOS. Table 7 presents the characteristics of the methodological approach used in the studies involving mobile platforms. , It shows the types of systems evaluated, the number of participants and their profiles, and the assistive technologies used.

Users encountered problems such as the absence of resources for enlarging content, unreachable help links, absence 
Table 4. Characteristics of accessibility inspections by specialists on websites.

\begin{tabular}{|c|c|c|c|c|c|}
\hline $\begin{array}{ll}\# & \text { of } \\
\text { tools } & \end{array}$ & Tools used & $\begin{array}{l}\# \text { of spe- } \\
\text { cialists }\end{array}$ & $\begin{array}{l}\text { Specialists' pro- } \\
\text { file }\end{array}$ & \# of aplications & Study involved \\
\hline 1 & ChromeVox & 3 & $\begin{array}{l}\text { A graduate stu- } \\
\text { dent and two ex- } \\
\text { perts }\end{array}$ & 1 & $\begin{array}{l}\text { (Rodrigues and Prietch, } \\
\text { 2018) }\end{array}$ \\
\hline $\begin{array}{l}\text { unavail- } \\
\text { able }\end{array}$ & unavailable & 1 & unavailable & 1 & (Galkute et al., 2020) \\
\hline 3 & $\begin{array}{l}\text { Achecker,To- } \\
\text { tal Validator, } \\
\text { NVDA }\end{array}$ & 2 & $\begin{array}{l}\text { accessibility } \\
\text { testers }\end{array}$ & 17 & (Doush and AlMeraj, 2019) \\
\hline $\begin{array}{l}\text { unavail- } \\
\text { able }\end{array}$ & unavailable & 5 & unavailable & 100 & (Wentz et al., 2019) \\
\hline $\begin{array}{l}\text { unavail- } \\
\text { able }\end{array}$ & unavailable & 3 & $\begin{array}{l}\text { Two professors } \\
\text { of multimedia } \\
\text { and computer en- } \\
\text { gineering and an } \\
\text { IHC researcher }\end{array}$ & 1 & (Gonçalves et al., 2018) \\
\hline $\begin{array}{l}\text { unavail- } \\
\text { able }\end{array}$ & unavailable & 7 & $\begin{array}{l}\text { Three founders } \\
\text { of the evaluated } \\
\text { site, an interface } \\
\text { and database } \\
\text { programmer, two } \\
\text { web developers } \\
\text { and an IHC } \\
\text { researcher }\end{array}$ & 1 & (Mátrai, 2018) \\
\hline $\begin{array}{l}\text { unavail- } \\
\text { able }\end{array}$ & unavailable & 3 & HCI researchers & 4 & (Aizpurua et al., 2015) \\
\hline 1 & JAWS & 1 & $\begin{array}{l}\text { accessibility ex- } \\
\text { perts }\end{array}$ & 1 & (Valencia et al., 2014) \\
\hline 1 & $\begin{array}{l}\text { An unspecified } \\
\text { screen reader }\end{array}$ & 8 & $\begin{array}{l}\text { Computer ex- } \\
\text { perts with prior } \\
\text { knowledge of } \\
\text { the WCAG } 2.0 \\
\text { guidelines }\end{array}$ & 4 & (Loureiro et al., 2014) \\
\hline $\begin{array}{l}\text { unavail- } \\
\text { able }\end{array}$ & unavailable & 1 & specialist & 1 & Galkute et al. (2020) \\
\hline
\end{tabular}

Table 5. Characteristics of accessibility inspections by specialists on mobile apps.

\begin{tabular}{|l|l|l|l|l|l|l|}
\hline $\begin{array}{l}\text { \# of } \\
\text { tools }\end{array}$ & $\begin{array}{l}\text { Tools used - } \\
\text { Mobile }\end{array}$ & \# of specialists & $\begin{array}{l}\text { Profile of the spe- } \\
\text { cialists }\end{array}$ & $\begin{array}{l}\text { \# of apli- } \\
\text { cations }\end{array}$ & Smartphone & Study involved \\
\hline 1 & TalkBack & 3 & $\begin{array}{l}2 \text { undergraduate } \\
\text { student specialists } \\
1 \text { IHC teacher }\end{array}$ & 6 & Android & $\begin{array}{l}(\text { de Oliveira et al., } \\
2016)\end{array}$ \\
\hline 1 & TalkBack & 4 & specialist & 10 & Android & $\begin{array}{l}(\text { Carvalho et al., } \\
2016)\end{array}$ \\
\hline
\end{tabular}

of feedback, inappropriate textual content, and inappropriate title. Table 15 (in the Appendix) presents the accessibility issues identified by the twenty-six studies.

\subsubsection{Common Problems}

Seventeen barriers were found on both mobile and web platforms. Those problems were the lack of labels, inappropriate link destination, too much information, absence of alternative text, empty links, insufficient contrast, incompatibility of technologies, absence of titles, inappropriate description in controls, absence of resources for expansion, unreachable help link, absence of feedback, inappropriate textual content, inappropriate title, inconsistent content organization, images, resize text and spacing, pause, stop, hide. It is clear that mobile and website developers still need better accessibility practices.

\subsection{Problems encountered by different meth- ods}

In the selected studies analysis, several problems of accessibility were collected, resulting from the use of different types of accessibility evaluations. There are cases where an acces- 
Table 6. Characteristics of user evaluations on websites.

\begin{tabular}{|c|c|c|c|c|c|}
\hline $\begin{array}{l}\text { Num- } \\
\text { ber of } \\
\text { AT }\end{array}$ & AT used & \# of participants & $\begin{array}{l}\text { Profile of the } \\
\text { participants }\end{array}$ & Number of sites & Study involved \\
\hline 1 & NVDA & 2 & only blind & 1 & $\begin{array}{l}\text { Zitkus et al. } \\
(2016)\end{array}$ \\
\hline $\begin{array}{l}\text { unavail- } \\
\text { able }\end{array}$ & unavailable & 9 & only blind & 3 & $\begin{array}{l}\text { (Loureiro et al., } \\
\text { 2015) }\end{array}$ \\
\hline 2 & $\begin{array}{l}\text { NVDA ad an un- } \\
\text { specified screen } \\
\text { reader }\end{array}$ & 4 & $\begin{array}{l}\text { One deaf and } \\
\text { three blind }\end{array}$ & 1 & $\begin{array}{l}\text { (Rodrigues and } \\
\text { Prietch, 2018) }\end{array}$ \\
\hline 2 & JAWS e VoiceOver & 11 & only blind & 4 & $\begin{array}{l}\text { (Aizpurua et al., } \\
\text { 2014) }\end{array}$ \\
\hline 3 & $\begin{array}{l}\text { JAWS, NVDA e } \\
\text { VoiceOver }\end{array}$ & 11 & only blind & unavailable & $\begin{array}{l}\text { Pereira and } \\
\text { Archambault, } \\
2018 \text { ) }\end{array}$ \\
\hline 3 & $\begin{array}{l}\text { JAWS, Zoom Text } \\
\text { e Window-Eyes }\end{array}$ & 8 & $\begin{array}{l}\text { Six blind and } \\
\text { two with low vi- } \\
\text { sion }\end{array}$ & unavailable & (Power, 2018) \\
\hline 3 & $\begin{array}{l}\text { JAWS, NVDA and } \\
\text { VoiceOver }\end{array}$ & 20 & only blind & 1 & $\begin{array}{l}\text { (Gonçalves } \\
\text { et al., 2018) }\end{array}$ \\
\hline 1 & JAWS & 12 & $\begin{array}{l}\text { Eight blind and } \\
\text { four with nor- } \\
\text { mal vision }\end{array}$ & 1 & $\begin{array}{l}\text { (Gadde and Bol- } \\
\text { chini, 2014) }\end{array}$ \\
\hline $\begin{array}{l}\text { unavail- } \\
\text { able }\end{array}$ & unavailable & 24 & $\begin{array}{l}\text { Seventeen } \\
\text { blind, two } \\
\text { legally blind, } \\
\text { three with low } \\
\text { vision, one with } \\
\text { motor disability } \\
\text { and one blind } \\
\text { with motor } \\
\text { disability }\end{array}$ & 1 & (Mátrai, 2018) \\
\hline 2 & $\begin{array}{ll}\text { JAWS } & \text { and } \\
\text { VoiceOver } & \end{array}$ & 11 & only blind & 4 & $\begin{array}{l}\text { (Aizpurua et al., } \\
\text { 2015) }\end{array}$ \\
\hline 2 & $\begin{array}{l}\text { JAWS } \\
\text { VoiceOver }\end{array}$ & 22 & $\begin{array}{l}\text { Eleven blind } \\
\text { and eleven with } \\
\text { normal vision }\end{array}$ & unavailable & $\begin{array}{l}\text { (Abdolrahmani } \\
\text { and Kuber, } \\
\text { 2016) }\end{array}$ \\
\hline 1 & Sense Reader & 24 & $\begin{array}{l}\text { Twenty-three } \\
\text { blind and one } \\
\text { with low vision }\end{array}$ & 10 & $(\mathrm{Yi}, 2020)$ \\
\hline $\begin{array}{l}\text { unavail- } \\
\text { able }\end{array}$ & unavailable & 5 & $\begin{array}{l}\text { Three blind and } \\
\text { two with low vi- } \\
\text { sion }\end{array}$ & 7 & $\begin{array}{l}\text { (Archambault } \\
\text { et al., 2017) }\end{array}$ \\
\hline 1 & JAWS & 2 & blind & 1 & $\begin{array}{l}\text { Fernandes et al. } \\
(2015)\end{array}$ \\
\hline 1 & JAWS & 19 & only blind & 3 & $\begin{array}{l}\text { (Fernandes } \\
\text { et al., 2015) }\end{array}$ \\
\hline $\begin{array}{l}\text { unavail- } \\
\text { able }\end{array}$ & unavailable & 5 & low vision & 40 & $\begin{array}{l}\text { (Acosta-Vargas } \\
\text { et al., 2019c) }\end{array}$ \\
\hline $\begin{array}{l}\text { unavail- } \\
\text { able }\end{array}$ & unavailable & 25 & low vision & 5 & $\begin{array}{l}\text { (Akram and } \\
\text { Bt Sulaiman, } \\
2020)\end{array}$ \\
\hline
\end{tabular}

sibility problem has been identified by one single method, but there are situations where two or three methods identified problems of accessibility. Those unique problems do not characterize problem instances as in the studies of Carvalho et al. Carvalho et al. (2018b) or Power et al. Power et al. (2012)', as such information was not available in all studies. Thus, considering the accessibility problems identified, there are thirty-eight types of unique problems. For a better understanding of these results and considering unique problems, Table
8 and Table 9 shows the number of problems identified by the three methods, the number of unique problems encountered by only one method, the number of problems identified by two methods, and the number of problems identified by each method. Figures 1 and 2 show the types of problems found in a Venn diagram in web and mobile platforms. In the studies, 311 problem instances were found, of which 200 occurrences are on the web platform, and 111 occurrences are on the mobile platform. 
Table 7. Characteristics of user evaluations on mobile apps.

\begin{tabular}{|c|c|c|c|c|c|c|}
\hline $\begin{array}{l}\text { Num- } \\
\text { ber of } \\
\text { AT }\end{array}$ & AT used & \# of participants & $\begin{array}{l}\text { Profile of the } \\
\text { participants }\end{array}$ & apps evaluated & Study involved & $\begin{array}{l}\text { System Smart- } \\
\text { phone }\end{array}$ \\
\hline 2 & $\begin{array}{l}\text { TalkBack and } \\
\text { VoiceOver }\end{array}$ & 10 & $\begin{array}{l}\text { Six blind and } \\
\text { four with nor- } \\
\text { mal vision }\end{array}$ & 4 & $\begin{array}{l}\text { (Carvalho et al., } \\
\text { 2018b) }\end{array}$ & Android and iOs \\
\hline $\begin{array}{l}\text { unavail- } \\
\text { able }\end{array}$ & unavailable & 5 & blind & 1 & $\begin{array}{l}\text { (da Silva et al., } \\
\text { 2016b) }\end{array}$ & unavailable \\
\hline $\begin{array}{l}\text { unavail- } \\
\text { able }\end{array}$ & unavailable & unavailable & low vision & 4 & $\begin{array}{l}\text { (Acosta-Vargas } \\
\text { et al., 2019a) }\end{array}$ & unavailable \\
\hline $\begin{array}{l}\text { unavail- } \\
\text { able }\end{array}$ & unavailable & 5 & low vision & 5 & $\begin{array}{l}\text { (Acosta-Vargas } \\
\text { et al., 2020) }\end{array}$ & unavailable \\
\hline 1 & VoiceOver & 3 & $\begin{array}{l}\text { blind graduate } \\
\text { student }\end{array}$ & 3 & $\begin{array}{l}\text { (Park et al., } \\
2019)\end{array}$ & iOs \\
\hline 1 & TalkBack & 5 & blind & 1 & $\begin{array}{l}\text { (da Silva et al., } \\
2018 \text { b) }\end{array}$ & Android \\
\hline 1 & Tablet & 5 & low vision & 1 & $\begin{array}{l}\text { (Kulpa and } \\
\text { Amaral, 2014) }\end{array}$ & Android and iOs \\
\hline 1 & TalkBack & 20 & $\begin{array}{l}7 \text { blind, } 7 \text { visual } \\
\text { impaired, } 6 \text { nor- } \\
\text { mal vision }\end{array}$ & 1 & $\begin{array}{l}\text { (Kim et al., } \\
2016)\end{array}$ & Android \\
\hline
\end{tabular}

Table 8. Problems found on the web platform

\begin{tabular}{|l|l|l|}
\hline Identification & \# of Barriers & Percentage \\
\hline All & 11 & $19.64 \%$ \\
\hline Automated & 3 & $5.36 \%$ \\
\hline Automated and specialist & 2 & $3.57 \%$ \\
\hline Automated and user & 5 & $8.93 \%$ \\
\hline User and specialist & 14 & $25.00 \%$ \\
\hline Specialist & 10 & $17.86 \%$ \\
\hline User & 11 & $19.64 \%$ \\
\hline Total & 56 & $100.00 \%$ \\
\hline
\end{tabular}

Table 9. Problems found on the mobile platform

\begin{tabular}{|l|l|l|}
\hline Identification & \# of Barriers & Percentage \\
\hline All & 4 & $5.63 \%$ \\
\hline Automated & 3 & $4.23 \%$ \\
\hline Automated and specialist & 0 & $0 \%$ \\
\hline Automated and user & 4 & $5.63 \%$ \\
\hline User and specialist & 7 & $9.86 \%$ \\
\hline Specialist & 9 & $12.68 \%$ \\
\hline User & 44 & $61.97 \%$ \\
\hline Total & 71 & $100.00 \%$ \\
\hline
\end{tabular}

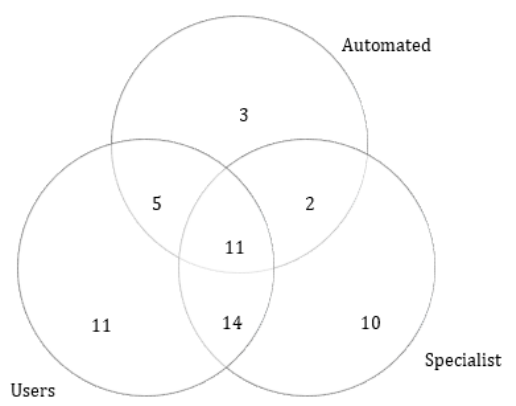

Figure 1. Venn diagram - Distribution of coverage of problems on the web platform

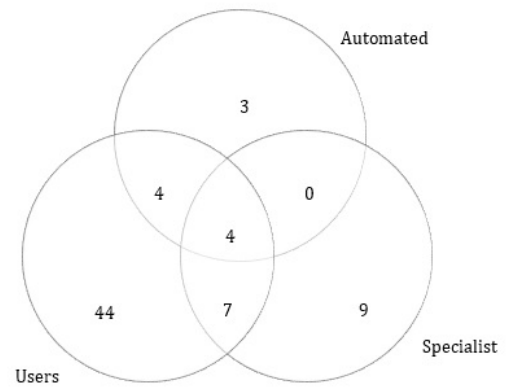

Figure 2. Distribution of coverage of problems on the mobile platform

\section{Discussion}

The results obtained show characteristics of each type of accessibility evaluation method for the web and mobile platforms. The benefits and limitations of inspections and tests are presented, providing more knowledge on visually impaired people's use of applications.

\subsection{Problems identified by different methods}

Question RQ1 was defined as "Among the problems identified in accessibility evaluations, what are problems found by any combinations of methods?". To answer this question, it is necessary to observe the results presented in Table 8 on websites and Table 9 on mobile. On evaluations of websites, eleven accessibility problems were identified by automated assessments, expert inspections, and user assessments.

We were surprised to find that the most commonly encountered problems in Tables 10,12 and 14 still included common issues encountered since early studies on accessibility, such as the absence of (i) alternative text, (ii) labels and contrast, and (iii) headings. Accessibility problems identified by the three methods are relevant in terms of accessibility evaluation operationalization. Many problems may prevent the users' tasks execution and are serious issues. It is positive that even automated evaluations can identify those problems, meaning 
that they can be identified early in the development process.

These problems can be easily solved in many cases. For example, the lack of alternative text may be fixed by adding content with alternative text (alt="description of information"). The violation of such simple principles shows that deeper issues need to be investigated to bring accessibility into the development process of both web and mobile applications.

The results show that the use of automated tools and manual inspections can optimize the performance of assessments by users, enabling such problems to be addressed found even before testing with users.

Answering RQ1 specifically in the case of mobile apps, the results presented in Table 9 provide insight into the types of problems encountered. Four accessibility problems were identified by automated assessments, expert inspections and user evaluations.

The problems presented in Tables 11,13 and 15 show that the most common violations were: Insufficient contrast, Inadequate navigation sequence, Visible focus. It is important to note that even with few studies using automated tools in the mobile context, the tools have identified relevant problems, considering they have had a shorter evolution time than automated web accessibility evaluation tools.

We can see that the number of problems encountered by all mobile platform methods is lower than the web platform. Perhaps this difference is due to the number of studies using automated tools on the web and mobile devices. There are still few studies on the coverage of automated tools for mobile.

\subsection{Problems identified by two methods}

Research question 2 (RQ2) was stated as "What are the benefits and limitations of each method for evaluating accessibility on the web?". According to the results presented in Table 8 , (i) five problems were found by automated inspections, and expert inspections and user tests identified tests with users and (ii) fourteen problems. Therefore, the discussion of this research question focuses on the problems with experts and users.

The problems encountered by users and experts were: Absence of contrast feature, Too much information, Inaccessible help link, Absence of feedback, Unexpected changes, Inappropriate alternate text, Inconsistent content organization, Inappropriate feedback, Keyboard, Location, Error identification, Color usage, Pause-Stop-Hide, Description of audio or alternative media (pre-recorded) and structural issues in the analysis of interactive elements.

Although the accessibility problems identified by all methods are relevant, it is important to highlight that the problems encountered by expert inspections and user tests have particular relevance. Many such problems are related to the inadequacy of the interface components rather than by the absence of specific accessibility features, as is normally the case of problems encountered by automated tools. In this sense, the inadequacy in one element can do more damage to usability than just the absence of a feature. For example, inappropriate text prevents access to non-textual content but does not cause errors in automated evaluations. However, unexpected changes can cause further damage to the interaction if the user does not know the reason for the change. The absence of feedback can lead the user to perform the same activity over and over again.

Research question 3 (RQ3) was stated as "What are the benefits and limitations of each method for evaluating accessibility on mobile platforms?". According to the results presented in Table 9, (i) four problems were found by automated inspections and tests with users, and (ii) seven problems were identified by expert inspections and user tests.

The problems encountered by users and experts were: Too much information, Absence of resources for expansion, Location, Keyboard, Images, Inadequate navigation sequence and Absence of titles.

Thus, results with problems found only by expert inspections and user tests corroborate other results found in the literature Vigo et al. (2013), that highlighted the drawbacks of using only automatic assessments and considering the relevance of the problems found only with the involvement of users and experts.

\subsection{Mobile and Web platforms}

When we analyze Table 10, 12, 14 and 15, it is possible to verify that most problems in the study were identified the web platform, totaling $64.30 \%$. Table 11,5 and 15 show that problems encountered on mobile platforms totalled $35.30 \%$.

It was noteworthy that fewer studies have conducted largescale evaluations of mobile apps using automated evaluations tools. This type of study has been widespread in the literature focusing on Web accessibility. This might be one possible explanation for the limited number of problems identified on mobile apps.

There has been an increasing number of studies focusing on the accessibility of mobile apps. However, in the last seven years, they are still fewer in comparison to web accessibility studies.

After analyzing the data, we verified that barriers are found on web and mobile platforms. Those issues have common aspects, even if implemented with different technologies. They show that more recent endeavours to promote mobile accessibility can count on many lessons already learnt in web accessibility research, while more particular issues in the platform are investigated.

\subsection{Benefits and Limitations of Different Meth- ods}

From the results obtained in our analysis, we can confirm that the main advantage of evaluations using automated tools is the agility in identifying problems early on in the development process. Inspections by specialists and user tests demand more time and planning to conduct and analyze studies. This result is in line with previous studies. Ivory (2013) pointed out that, in web accessibility evaluations, automated evaluations tools can speed up the process of identifying a subset of WCAG success criteria. Using automated evaluations may also have a lower cost and be easily applied even by less experienced developers and designers (Ivory, 2013; Jaeger, 2006).

Automated assessment tools for mobile platforms, due to their characteristic of verifying components dynamically, can encounter a more significant number of problems in relation 
to web tools that perform the verification in a static way (Quispe and Eler, 2018; Eler et al., 2018). Mobile accessibility evaluation tools had better performance (Eler et al., 2018) in encountering a larger number of instances of violations.

Inspections by specialists are very relevant to help identify accessibility problems that could go unnoticed in user evaluations that may not explore particular parts of large systems and problems that automated tools cannot identify. In the analysis in this study, for example, inspections by specialists identified duplicated links and difficulties to find the "help" pages. Further to this, inspections by specialists can also be applied earlier on in the development process (Lazar, 2005; Freire, 2012), as organizations may organize consultancy demands or in-house inspections, with less difficulty than the logistics of user evaluations. Inspections by specialists may also help to identify problems that users with visual disabilities might not be able to identify due to lack of accessibility (e.g. a vital image with a null textual description that would be ignored by a screen reader). However, effective accessibility inspections require well-trained professionals, who might always be readily available.

Finally, the main benefit of using user evaluations is the ability to identify critical problems that cannot be identified by other methods and that have an essential impact on users with disabilities. For example, in the results found in this mapping study, user evaluations revealed problems with the inconsistency in content organization and too much information on a page or screen. These problems may severely impact the performance of people with visual disabilities, impacting their interaction and navigation on websites and mobile applications. However, these methods may be costly to apply and require a wider range of participants. As pointed out by Gonçalves et al. (2018), the different experiences participants may have with screen readers vary significantly, and this may impact the results obtained in user evaluations. In the case of mobile evaluation, evaluations must involve participants who use different mobile devices, as accessibility resources and assistive technologies may also vary in different platforms.

\subsection{Most effective method}

This study analyzed the different contributions that accessibility assessment methods have to identify problems that affect visually impaired users on websites and mobile applications.

As shown in Table 8, for the web platform, of all types of unique problems, ten were identified only by inspections by experts, eleven were found only by user evaluations, and automated tools found three types of problems. On Table 9 , for the mobile platform, of all types of unique problems, nine were identified only by inspections by experts, fortyfour were found only by user evaluations, and automated tools found three types of problem. Despite being important productivity aids, automated tools cannot identify a broader range of accessibility problems. Expert inspections and user reviews are the most suitable methods to be used to identify more problems.

Along with using automated evaluation tools in earlier phases of the development process to identify more obvious problems more effectively, evaluations should incorporate inspections by specialists and user evaluations. This result is in line with the findings from Harrison and Petrie (2007), who showed that the severity of accessibility problems assigned by specialists and users were more in agreement than the priorities assigned by guidelines, for example.

\subsection{Most cost-effective method}

The fastest and less costly method is automated testing. It was able to identify ten problems on the mobile platform 8 and seven on the mobile platform 9 , its testing capability allows for repetitive tests in a few seconds (Eler et al., 2018; Mateus et al., 2020; Brajnik et al., 2011). Furthermore, the tools were able to find unique issues on both platforms, three for web and three for mobile. This shows that developers should use the tools in both web and mobile platforms to incorporate basic accessibility resources early in the development process.

\subsection{Impact of the issues encountered}

Several studies point out that as accessibility guidelines are not able to cover all violations (Power et al., 2012; Carvalho et al., 2018b). The WCAG is constantly being updated so that it can cover all accessibility violations.

To reduce the distances found on the platforms, it is necessary to carry out tests using the three methods produced in this study to improve accessibility, however, tests with high resource users. However, it is necessary to understand the difficulties developers have to apply as good accessibility practices.

The violations found can seriously affect users, especially in this period of the pandemic COVID-19 (Agarwal et al., 2020) that everyone was forced to follow protocols of social distancing, barriers such as non-text content users may have problems reading the screen because they did not inform the content, problems with contracting users with the low vision and color blind, information can pass without them seeing. Studies show that these barriers have a high degree of severity, indicating that the user must exert excessive effort to fulfil the task (Carvalho et al., 2018b; Rømen and Svanæs, 2012).

\section{Conclusion}

This study aimed at characterizing the main benefits and limitations of different accessibility evaluation methods focused on people with visual impairments on Web and mobile platforms, based on a mapping of the literature of the past seven years. The study analyzed thirty-eight papers that evaluated websites and mobile applications that involved evaluation by automated tools, inspections by specialists and user evaluations. The results build upon a previous study (Silva et al., 2019) covering web accessibility problems that analyzed nineteen studies.

The study discussed the main benefits of each type of method. Evaluations with automated tools are faster and can help find problems that would be difficult to find manually with repetitive tests Ivory (2013). Inspections by specialists can identify problems that other methods could go unnoticed and may help predict more common problems that could be 
fixed before user evaluations. User evaluations are the "goldstandard" in accessibility evaluations, as they can encounter the most relevant problems that impact users in the systems and that specialists and tools might not identify.

However, the study also identified limitations. Automated evaluations with tools are not able to identify the adequacy of accessibility resources in the context in which they are used (Brajnik et al., 2011). Inspections by specialists may take time to be carried out and still cannot reveal all problems that real users may encounter. The experience participants may impact user evaluations have with different assistive technologies and take a significant time to be performed (Gonçalves et al., 2018). Further to this, some problems are difficult to identify by people with visual disabilities due to their nature and require inspection by a specialist.

It is important to emphasize that although studies on accessibility problems found in mobile applications have great relevance since the tools can find relevant and significant problems (Mateus et al., 2020).

Therefore, when conducting accessibility assessments, the ideal is to use assessments involving user tests and inspections by experts, as these two methods combined can identify more number of absences and inadequacies of accessibility features on web pages. Automated tests are useful but should not be performed as only evaluation method when you want to check the accessibility of a website or at the end of its development.

Future work could examine the differences in the outcomes of evaluations performed in different countries. The present study focused on the types of problems encountered by different methods, and many included studies did not focus on a single country or place. However, considering specific cultural issues would bring important findings to understand accessibility problems.

\section{Acknowledgements}

We thank the reviewers for their careful analysis and constructive feedback. Their input was crucial for the improvement of this paper. We also thank Fundação de Amparo à Pesquisa do Estado de São Paulo (FAPESP), process 2020/05187-5 for funding the research group.

\section{References}

Abdolrahmani, A. and Kuber, R. (2016). Should i trust it when i cannot see it? credibility assessment for blind web users. In Proceedings of the 18th International ACM SIGACCESS Conference on Computers and Accessibility, pages 191-199.

Abou-Zahra, S. (2008). Web accessibility evaluation. In Harper, S. and Yesilada, Y., editors, Web Accessibility: A Foundation for Research, pages 79-106. Springer.

Acosta-Vargas, P., Salvador-Acosta, B., Zalakeviciute, R., Alexandrino, K., Pérez-Medina, J.-L., Rybarczyk, Y., and Gonzalez, M. (2020). Accessibility assessment of mobile meteorological applications for users with low vision. In International Conference on Applied Human Factors and Ergonomics, pages 199-205. Springer.
Acosta-Vargas, P., Salvador-Ullauri, L., Pérez-Medina, J. L., Zalakeviciute, R., and Hernandez, W. (2019a). Heuristic method of evaluating accessibility of mobile in selected applications for air quality monitoring. In International Conference on Applied Human Factors and Ergonomics, pages 485-495. Springer.

Acosta-Vargas, P., Salvador-Ullauri, L. A., and Luján-Mora, S. (2019b). A heuristic method to evaluate web accessibility for users with low vision. IEEE Access, 7:125634-125648.

Acosta-Vargas, P., Salvador-Ullauri, L. A., and Luján-Mora, S. (2019c). A heuristic method to evaluate web accessibility for users with low vision. IEEE Access, 7:125634-125648.

Agarwal, V., Poddar, S., and Karnavat, S. J. (2020). A study on growth of mobile banking in india during covid-19. PalArch's Journal of Archaeology of Egypt / Egyptology, 17:9461-9485.

Aizpurua, A., Arrue, M., Harper, S., and Vigo, M. (2014). Are users the gold standard for accessibility evaluation? In Proceedings of the 11th Web for All Conference, pages $1-4$.

Aizpurua, A., Arrue, M., and Vigo, M. (2015). Prejudices, memories, expectations and confidence influence experienced accessibility on the web. Computers in Human Behavior, 51:152-160.

Akram, M. and Bt Sulaiman, R. (2020). An empirical study to evaluate the accessibility of arabic websites by low vision users. In 2020 8th International Conference on Information Technology and Multimedia (ICIMU), pages 206-211.

Archambault, D. et al. (2017). Web widgets barriers for visually impaired users. Studies in Health Technology and Informatics, 242:836-842.

Brajnik, G. (2008). A comparative test of web accessibility evaluation methods. In Proceedings of the 10th international ACM SIGACCESS conference on Computers and accessibility, pages 113-120.

Brajnik, G., Yesilada, Y., and Harper, S. (2011). The expertise effect on web accessibility evaluation methods. HumanComputer Interaction, 26(3):246-283.

Carvalho, L. P., Dias, F. S., and Freire, A. P. (2018a). An analysis of five different native and web-hybrid platforms for building android apps and their accessibility for screen readers. SBC Journal on Interactive Systems, 9(3):20-33.

Carvalho, L. P. and Freire, A. P. (2017). Native or webhybrid apps? an analysis of the adequacy for accessibility of android interface components used with screen readers. In Proceedings of the XVI Brazilian Symposium on Human Factors in Computing Systems, IHC 2017, New York, NY, USA. Association for Computing Machinery.

Carvalho, L. P., Peruzza, B. P. M., Santos, F., Ferreira, L. P., and Freire, A. P. (2016). Accessible smart cities? inspecting the accessibility of brazilian municipalities' mobile applications. In Proceedings of the 15th Brazilian Symposium on Human Factors in Computing Systems, pages $1-10$.

Carvalho, M. C. N., Dias, F. S., Reis, A. G. S., and Freire, A. P. (2018b). Accessibility and usability problems encountered on websites and applications in mobile devices by blind and normal-vision users. In Proceedings of the 33rd 
Annual ACM Symposium on Applied Computing, SAC '18, page 2022-2029, New York, NY, USA. Association for Computing Machinery.

da Silva, C. F., Ferreira, S. B. L., and Ramos, J. a. F. M. (2016a). Whatsapp accessibility from the perspective of visually impaired people. In Proceedings of the 15th Brazilian Symposium on Human Factors in Computing Systems, IHC '16, New York, NY, USA. Association for Computing Machinery.

da Silva, C. F., Ferreira, S. B. L., and Ramos, J. F. M. (2016b). Whatsapp accessibility from the perspective of visually impaired people. In Proceedings of the 15th Brazilian Symposium on Human Factors in Computing Systems, pages $1-10$.

da Silva, C. F., Ferreira, S. B. L., and Sacramento, C. (2018a). Mobile application accessibility in the context of visually impaired users. In Proceedings of the 17th Brazilian Symposium on Human Factors in Computing Systems, IHC 2018, New York, NY, USA. Association for Computing Machinery.

da Silva, C. F., Ferreira, S. B. L., and Sacramento, C. (2018b). Mobile application accessibility in the context of visually impaired users. In Proceedings of the 17th Brazilian Symposium on Human Factors in Computing Systems, pages $1-10$.

de Oliveira, G. A. A., de Bettio, R. W., and Freire, A. P. (2016). Accessibility of the smart home for users with visual disabilities: an evaluation of open source mobile applications for home automation. In Proceedings of the 15th Brazilian Symposium on Human Factors in Computing Systems, pages 1-10.

Doush, I. and AlMeraj, Z. (2019). Evaluating the accessibility of kuwaiti e-government websites. Jordanian Journal of Computers and Information Technology (JJCIT), 5(03).

Eler, M. M., Rojas, J. M., Ge, Y., and Fraser, G. (2018). Automated accessibility testing of mobile apps. In 2018 IEEE 11th International Conference on Software Testing, Verification and Validation (ICST), pages 116-126. IEEE.

Fernandes, N., Guerreiro, T., Marques, D., and Carriço, L. (2015). Optimus web: selective delivery of desktop or mobile web pages. In Proceedings of the 12th Web for All Conference, pages 1-4.

Freire, A. P. (2012). Disabled people and the Web: Userbased measurement of accessibility. $\mathrm{PhD}$ thesis, University of York.

Gadde, P. and Bolchini, D. (2014). From screen reading to aural glancing: towards instant access to key page sections. In Proceedings of the 16th international ACM SIGACCESS conference on Computers \& accessibility, pages 67-74.

Galkute, M. et al. (2020). Improving the web accessibility of a university library for people with visual disabilities through a mixed evaluation approach. In International Conference on Human-Computer Interaction, pages 56-71. Springer.

Ghidini, E., Almeida, W. D. L., Manssour, I. H., and Silveira, M. S. (2016). Developing apps for visually impaired people: Lessons learned from practice. In 2016 49th Hawaii International Conference on System Sciences (HICSS), pages 5691-5700.

Gonçalves, R., Rocha, T., Martins, J., Branco, F., and Au-
Yong-Oliveira, M. (2018). Evaluation of e-commerce websites accessibility and usability: an e-commerce platform analysis with the inclusion of blind users. Universal Access in the Information Society, 17(3):567-583.

Governo Brasileiro (2014). emag - modelo de acessibilidade em governo eletro $\square$ nico. Retrieved September 11, 2020 from http://emag.governoeletronico.gov.br/.

Hanson, V. L. and Richards, J. T. (2013). Progress on website accessibility? ACM Trans. Web, 7(1).

Harrison, C. and Petrie, H. (2007). Severity of usability and accessibility problems in ecommerce and egovernment websites. In People and Computers XX-Engage, pages 255-262. Springer.

Ismail, A., Kuppusamy, K., and Nengroo, A. S. (2018). Multitool accessibility assessment of government department websites: a case-study with jkgad. Disability and Rehabilitation: Assistive Technology, 13(6):504-516.

ISO (2018). Iso 9241-11. usability: Definitions and concepts. International Organization for Standardization. Retrieved April 23, 2020 from https://www.iso.org/obp/ui/iso:std:iso:9241:-11:ed2:v1:en.

Ivory, M. Y. (2013). Automated Web Site Evaluation: Researchers' and Practioners' Perspectives, volume 4. Springer Science \& Business Media.

Jaeger, P. T. (2006). Assessing section 508 compliance on federal e-government web sites: A multi-method, usercentered evaluation of accessibility for persons with disabilities. Government Information Quarterly, 23(2):169-190.

Kim, H. K., Han, S. H., Park, J., and Park, J. (2016). The interaction experiences of visually impaired people with assistive technology: A case study of smartphones. International Journal of Industrial Ergonomics, 55:22-33.

Kulpa, C. C. and Amaral, F. G. (2014). Evaluation of tablet pc application interfaces with low vision users: Focusing on usability. In International Conference of Design, User Experience, and Usability, pages 273-284. Springer.

Lazar, J. (2005). Web usability: A user-centered design approach. Addison-Wesley Longman Publishing Co., Inc.

Loureiro, J. R., Cagnin, M. I., and Paiva, D. M. (2014). Web accessibility in social networking services. In International Conference on Computational Science and Its Applications, pages 586-601. Springer.

Loureiro, J. R., Cagnin, M. I., and Paiva, D. M. B. (2015). Analysis of web accessibility in social networking services through blind users' perspective and an accessible prototype. In International Conference on Computational Science and Its Applications, pages 117-131. Springer.

Mateus, D. A., Silva, C. A., Eler, M. M., and Freire, A. P. (2020). Accessibility of mobile applications: Evaluation by users with visual impairment and by automated tools. In Proceedings of the 19th Brazilian Symposium on Human Factors in Computing Systems, IHC '20, New York, NY, USA. Association for Computing Machinery.

Mátrai, R. K. (2018). How to make an electronic library accessible. The electronic library.

Mounika, P., Karia, D., Sharma, K., and Biswas, P. (2019). Accessibility evaluation of three important indian websites. In Research into Design for a Connected World, pages 
243-254. Springer.

Nogueira, T. C., Ferreira, D. J., Carvalho, S. T., and Berreta, L. O. (2017). Evaluating responsive web design's impact on blind users. IEEE MultiMedia, 24(2):86-95.

Park, K., So, H.-J., and Cha, H. (2019). Digital equity and accessible moocs: Accessibility evaluations of mobile moocs for learners with visual impairments. Australasian Journal of Educational Technology, 35(6):48-63.

Pereira, L. S. and Archambault, D. (2018). Correlating navigation barriers on web 2.0 with accessibility guidelines. In International Conference on Computers Helping People with Special Needs, pages 13-21. Springer.

Petrie, H. and Bevan, N. (2009). The evaluation of accessibility, usability, and user experience. In Stephanidis, C., editor, The Universal Access Handbook, pages 1-16. CRC Press.

Power, C., Freire, A., Petrie, H., and Swallow, D. (2012). Guidelines are only half of the story: accessibility problems encountered by blind users on the web. In Proceedings of the SIGCHI conference on human factors in computing systems, pages 433-442.

Power, C., Petrie, H., Freire, A. P., and Swallow, D. (2011). Remote evaluation of wcag 2.0 techniques by web users with visual disabilities. In International Conference on Universal Access in Human-Computer Interaction, pages 285-294. Springer.

Power, J. A. (2018). Ebsco information services usability study on accessibility. Reference Services Review.

Pribeanu, C., Fogarassy-Neszly, P., and Pătru, A. (2014). Municipal web sites accessibility and usability for blind users: preliminary results from a pilot study. Universal access in the information society, 13(3):339-349.

Quispe, F. E. M. and Eler, M. M. (2018). Accessibility recommendations for mobile applications: a contribution to the brazilian digital government standards. In Proceedings of the XIV Brazilian Symposium on Information Systems, pages $1-8$.

Rodrigues, L. A. and Prietch, S. S. (2018). Analysis, redesign and validation of accessibility resources applied to an official electronic journal for the promotion of equal access to public acts. In Proceedings of the 17th Brazilian Symposium on Human Factors in Computing Systems, pages $1-10$.

Rømen, D. and Svanæs, D. (2012). Validating wcag versions 1.0 and 2.0 through usability testing with disabled users. Universal Access in the Information Society, 11(4):375-385.

Rysavy, M. D. and Michalak, R. (2020). Assessing the accessibility of library tools \& services when you aren't an accessibility expert: Part 1. Journal of Library Administration, 60(1):71-79.

Silva, C. A., de Oliveira, A. F., Mateus, D. A., Costa, H. A. X., and Freire, A. P. (2019). Types of problems encountered by automated tool accessibility assessments, expert inspections and user testing: a systematic literature mapping. In Proceedings of the 18th Brazilian Symposium on Human Factors in Computing Systems, pages 1-11.

Stephanidis, C. (2009). The universal access handbook. CRC Press.
Valencia, X., Arrue, M., Rojas-Valduciel, H., and Moreno, L. (2014). Interdependent components for the development of accessible xul applications for screen reader users. In WEBIST (2), pages 65-73.

Vigo, M., Brown, J., and Conway, V. (2013). Benchmarking web accessibility evaluation tools: Measuring the harm of sole reliance on automated tests. In Proceedings of the 10th International Cross-Disciplinary Conference on Web Accessibility, W4A '13, New York, NY, USA. Association for Computing Machinery.

W3C (2016). Web accessibility evaluation tools list. Retrieved December 15, 2020 from https://www.w3.org/WAI/ER/tools/.

W3C (2019). http://www.w3c.br/pub/materiais/publicacoesw3c/cartilha-w3cbr- acessibilidade-webfasciculo-i.html. Retrieved April 15, 2019 from https://www.w3.org/WAI/ER/tools/.

W3C (2020). https://www.w3.org/wai/standardsguidelines/wcag/. Retrieved April 15, 2019 from https://www.w3.org/WAI/ER/tools/.

Wentz, B., Pham, D., Feaser, E., Smith, D., Smith, J., and Wilson, A. (2019). Documenting the accessibility of 100 us bank and finance websites. Universal Access in the Information Society, 18(4):871-880.

Yan, S. and Ramachandran, P. (2019). The current status of accessibility in mobile apps. ACM Transactions on Accessible Computing (TACCESS), 12(1):1-31.

Yi, Y. J. (2020). Web accessibility of healthcare web sites of korean government and public agencies: a user test for persons with visual impairment. Universal Access in the Information Society, 19(1):41-56.

Zaphiris, P. (2007). Web usability: A user-centered design approach by jonathan lazar (2006): Isbn 0321321359, publisher: Addison-wesley. Univers. Access Inf. Soc., 6(1):115.

Zitkus, E., Brigatto, A. C., Ferrari, A. L. M., Bonfim, G. H., Carvalho Filho, I. F., Reis, T. D., Medola, F. O., and Paschoarelli, L. C. (2016). Accessibility and usability of websites intended for people with disabilities: a preliminary study. In International Conference of Design, User Experience, and Usability, pages 678-688. Springer.

\section{A Appendix}


Table 10. Accessibility problems encountered by automated evaluation tools on websites.

\begin{tabular}{|c|c|c|c|}
\hline Barrier code & Barrier & Description & Studies - web \\
\hline 1 & Absence of labels & $\begin{array}{l}\text { Form fields that have no labels on } \\
\text { their purpose. }\end{array}$ & $\begin{array}{l}\text { (Zitkus et al., 2016; Gonçalves et al., 2018; } \\
\text { Loureiro et al., 2014; Galkute et al., 2020; } \\
\text { Mounika et al., 2019; Rysavy and Michalak, } \\
\text { 2020) }\end{array}$ \\
\hline 2 & $\begin{array}{l}\text { Inappropriate link } \\
\text { destination }\end{array}$ & $\begin{array}{l}\text { Links that do not direct the user to } \\
\text { the page they are intended for. }\end{array}$ & (Gonçalves et al., 2018) \\
\hline 5 & Absence of headers & $\begin{array}{l}\text { Pages that do not have headings to } \\
\text { indicate main content or sections. }\end{array}$ & $\begin{array}{l}\text { (Gonçalves et al., 2018; Ismail et al., 2018; } \\
\text { Mounika et al., 2019; Rysavy and Michalak, } \\
\text { 2020) }\end{array}$ \\
\hline 6 & $\begin{array}{l}\text { Absence of alterna- } \\
\text { tive text }\end{array}$ & $\begin{array}{l}\text { Non-text content that does not have } \\
\text { alternative text. }\end{array}$ & $\begin{array}{l}\text { (Gonçalves et al., 2018; Ismail et al., 2018; } \\
\text { Loureiro et al., 2014; Galkute et al., 2020) }\end{array}$ \\
\hline 7 & Empty links & $\begin{array}{l}\text { Links that do not have a description } \\
\text { of their purpose. }\end{array}$ & $\begin{array}{l}\text { (Zitkus et al., 2016; Ismail et al., 2018; } \\
\text { Loureiro et al., 2014; Rysavy and Michalak, } \\
\text { 2020) }\end{array}$ \\
\hline 8 & Language not set & $\begin{array}{l}\text { Content that has no language de- } \\
\text { fined. }\end{array}$ & $\begin{array}{l}\text { Ismail et al. (2018); Rysavy and Michalak } \\
\text { (2020) }\end{array}$ \\
\hline 9 & $\begin{array}{l}\text { Duplicate informa- } \\
\text { tion }\end{array}$ & $\begin{array}{l}\text { Content that presents duplicate tex- } \\
\text { tual information, such as alternative } \\
\text { text for non-text content. }\end{array}$ & $\begin{array}{l}\text { (Gonçalves et al., 2018; Loureiro et al., 2014; } \\
\text { Rysavy and Michalak, 2020) }\end{array}$ \\
\hline 11 & $\begin{array}{l}\text { Absence of head- } \\
\text { ings in tables }\end{array}$ & $\begin{array}{l}\text { Tables that do not have identifier } \\
\text { headings for their elements in each } \\
\text { cell. }\end{array}$ & (Gonçalves et al., 2018) \\
\hline 12 & Insufficient contrast & Bad contrast ratio. & $\begin{array}{l}\text { (Gonçalves et al., 2018; Galkute et al., 2020; } \\
\text { Mounika et al., 2019) }\end{array}$ \\
\hline 13 & $\begin{array}{l}\text { Keyboard inaccessi- } \\
\text { ble content }\end{array}$ & $\begin{array}{l}\text { Content not accessible by keyboard, } \\
\text { such as functionality or information. }\end{array}$ & (Gonçalves et al., 2018) \\
\hline 14 & $\begin{array}{l}\text { Incompatibility of } \\
\text { technologies }\end{array}$ & $\begin{array}{l}\text { Incompatible content with screen } \\
\text { readers, such as flash }\end{array}$ & (Gonçalves et al., 2018) \\
\hline 15 & Absence of titles & $\begin{array}{l}\text { Pages that do not have an identifying } \\
\text { title. }\end{array}$ & (Gonçalves et al., 2018; Loureiro et al., 2014) \\
\hline 16 & $\begin{array}{l}\text { Inadequate header } \\
\text { levels }\end{array}$ & $\begin{array}{l}\text { Sections or subsections that have an } \\
\text { incorrect level of headings. }\end{array}$ & (Loureiro et al., 2014) \\
\hline 17 & $\begin{array}{l}\text { Inappropriate de- } \\
\text { scription in controls }\end{array}$ & $\begin{array}{l}\text { Controls, such as a link or button, } \\
\text { that have an inappropriate descrip- } \\
\text { tion. }\end{array}$ & (Mounika et al., 2019) \\
\hline 20 & $\begin{array}{l}\text { Inadequate naviga- } \\
\text { tion sequence }\end{array}$ & $\begin{array}{l}\text { Content that does not allow an ade- } \\
\text { quate navigation sequence by screen } \\
\text { readers. }\end{array}$ & (Mounika et al., 2019) \\
\hline 27 & $\begin{array}{l}\text { Absence of short- } \\
\text { cuts }\end{array}$ & $\begin{array}{l}\text { Absence of shortcuts to access main } \\
\text { content. }\end{array}$ & (Loureiro et al., 2014) \\
\hline 41 & Visible Focus & $\begin{array}{l}\text { The user cannot understand what the } \\
\text { system expects him to do }\end{array}$ & (Galkute et al., 2020) \\
\hline 47 & Order Focus & $\begin{array}{l}\text { The components that can be focused } \\
\text { are focused on in an order that pre- } \\
\text { serves meaning and operability }\end{array}$ & $\begin{array}{l}\text { (Galkute et al., 2020; Doush and AlMeraj, } \\
\text { 2019) }\end{array}$ \\
\hline 48 & Images & $\begin{array}{l}\text { Text is used to convey information } \\
\text { instead of images of text. }\end{array}$ & (Galkute et al., 2020; Mounika et al., 2019) \\
\hline 51 & Spacing & spacing between images, text, forms & (Rysavy and Michalak, 2020) \\
\hline
\end{tabular}


Table 11. Accessibility problems encountered by automated evaluation tools on mobile applications

\begin{tabular}{|c|c|c|c|}
\hline Barrier code & Barrier & Description & Studies - mobile \\
\hline 1 & Absence of labels & $\begin{array}{l}\text { Form fields that have no labels on } \\
\text { their purpose. }\end{array}$ & (Mateus et al., 2020) \\
\hline 17 & $\begin{array}{l}\text { Inappropriate de- } \\
\text { scription in controls }\end{array}$ & $\begin{array}{l}\text { Controls, such as a link or button, } \\
\text { that have an inappropriate descrip- } \\
\text { tion. }\end{array}$ & $\begin{array}{l}\text { (Mateus et al., 2020; Yan and Ramachandran, } \\
\text { 2019) }\end{array}$ \\
\hline 67 & Target Size & Font size, button. & $\begin{array}{l}\text { (Mateus et al., 2020; Yan and Ramachandran, } \\
\text { 2019) }\end{array}$ \\
\hline 9 & $\begin{array}{l}\text { Duplicate informa- } \\
\text { tion }\end{array}$ & $\begin{array}{l}\text { Content that presents duplicate tex- } \\
\text { tual information, such as alternative } \\
\text { text for non-text content. }\end{array}$ & (Mateus et al., 2020) \\
\hline 12 & Insufficient contrast & Bad contrast ratio. & $\begin{array}{l}\text { (Mateus et al., 2020; Yan and Ramachandran, } \\
\text { 2019) }\end{array}$ \\
\hline 14 & $\begin{array}{l}\text { Incompatibility of } \\
\text { technologies }\end{array}$ & $\begin{array}{l}\text { Incompatible content with screen } \\
\text { readers, such as flash }\end{array}$ & (Yan and Ramachandran, 2019) \\
\hline 17 & $\begin{array}{l}\text { Inappropriate de- } \\
\text { scription in controls }\end{array}$ & $\begin{array}{l}\text { Controls, such as a link or button, } \\
\text { that have an inappropriate descrip- } \\
\text { tion. }\end{array}$ & Mateus et al. (2020) \\
\hline 20 & $\begin{array}{l}\text { Inadequate naviga- } \\
\text { tion sequence }\end{array}$ & $\begin{array}{l}\text { Content that does not allow an ade- } \\
\text { quate navigation sequence by screen } \\
\text { readers. }\end{array}$ & (Mateus et al., 2020) \\
\hline 41 & Visible Focus & $\begin{array}{l}\text { The user cannot understand what the } \\
\text { system expects him to do. }\end{array}$ & (Mateus et al., 2020) \\
\hline 34 & Inappropriate title & $\begin{array}{l}\text { Page title that does not correctly de- } \\
\text { scribe the content. }\end{array}$ & $\begin{array}{l}\text { (Mateus et al., 2020; Yan and Ramachandran, } \\
\text { 2019) }\end{array}$ \\
\hline 51 & Spacing & spacing between images, text, forms & $\begin{array}{l}\text { (Mateus et al., 2020; Yan and Ramachandran, } \\
\text { 2019) }\end{array}$ \\
\hline
\end{tabular}


Table 12. Accessibility problems encountered by expert inspections on websites

\begin{tabular}{|c|c|c|c|}
\hline Barrier code & Barrier & Description & Studies - web \\
\hline 19 & $\begin{array}{l}\text { Duplicate short- } \\
\text { cuts }\end{array}$ & $\begin{array}{l}\text { Use of a single shortcut to more than one con- } \\
\text { tent. }\end{array}$ & (Pribeanu et al., 2014) \\
\hline 30 & $\begin{array}{l}\text { Absence of alter- } \\
\text { native to captcha }\end{array}$ & Captcha element that has no audio alternative. & (Pribeanu et al., 2014) \\
\hline 27 & $\begin{array}{l}\text { Absence of short- } \\
\text { cuts }\end{array}$ & Absence of shortcuts to access main content. & $\begin{array}{l}\text { (Rodrigues and Prietch, } \\
\text { 2018; Loureiro et al., } \\
\text { 2014) }\end{array}$ \\
\hline 5 & $\begin{array}{l}\text { Absence of head- } \\
\text { ers }\end{array}$ & $\begin{array}{l}\text { Pages that do not have headings to indicate main } \\
\text { content or sections. }\end{array}$ & (Pribeanu et al., 2014) \\
\hline 21 & $\begin{array}{l}\text { Absence of alter- } \\
\text { native to captcha }\end{array}$ & $\begin{array}{l}\text { Content that does not distinguish between links, } \\
\text { such as active, visited and unvisited. }\end{array}$ & (Gonçalves et al., 2018) \\
\hline 26 & $\begin{array}{l}\text { Absence of feed- } \\
\text { back }\end{array}$ & $\begin{array}{l}\text { When using any means of access, such as a link } \\
\text { or button, the user does not receive feedback. }\end{array}$ & $\begin{array}{l}\text { (Gonçalves et al., 2018; } \\
\text { Loureiro et al., 2014) }\end{array}$ \\
\hline 18 & $\begin{array}{lr}\text { Absence } & \text { of } \\
\text { resources } & \text { for } \\
\text { expansion } & \\
\end{array}$ & Absence of resources to expand textual content. & $\begin{array}{l}\text { (Wentz et al., 2019; } \\
\text { Pribeanu et al., 2014; } \\
\text { de Oliveira et al., 2016) }\end{array}$ \\
\hline 3 & $\begin{array}{l}\text { Absence of con- } \\
\text { trast feature }\end{array}$ & $\begin{array}{l}\text { Absence of feature to increase contrast level } \\
\text { between text and page background. }\end{array}$ & (Pribeanu et al., 2014) \\
\hline 1 & Absence of labels & Form fields that have no labels on their purpose. & $\begin{array}{l}\text { (Wentz et al., 2019; } \\
\text { Loureiro et al., 2014; } \\
\text { Valencia et al., 2014) }\end{array}$ \\
\hline 6 & $\begin{array}{l}\text { Absence of alter- } \\
\text { native text }\end{array}$ & $\begin{array}{l}\text { Non-text content that does not have alternative } \\
\text { text. }\end{array}$ & $\begin{array}{l}\text { (Wentz et al., 2019; } \\
\text { Pribeanu et al., 2014; } \\
\text { Loureiro et al., 2014; } \\
\text { Galkute et al., 2020) }\end{array}$ \\
\hline 15 & Absence of titles & Pages that do not have an identifying title. & $\begin{array}{l}\text { (Gonçalves et al., 2018; } \\
\text { Galkute et al., 2020; } \\
\begin{array}{l}\text { Doush and AlMeraj, } \\
2019)\end{array}\end{array}$ \\
\hline 24 & Low performance & Loading pages is slow. & $\begin{array}{l}\text { (Gonçalves et al., 2018; } \\
\text { Doush and AlMeraj, } \\
2019)\end{array}$ \\
\hline 10 & $\begin{array}{l}\text { Undeclared } \\
\text { mandatory fields }\end{array}$ & $\begin{array}{l}\text { Form fields whose mandatory filling is not iden- } \\
\text { tified by screen readers. }\end{array}$ & (Loureiro et al., 2014) \\
\hline 44 & $\begin{array}{l}\text { Sensory Charac- } \\
\text { teristics }\end{array}$ & $\begin{array}{l}\text { Instructions do not rely only on shape, color, } \\
\text { size, visual location, orientation or sound }\end{array}$ & $\begin{array}{l}\text { (Doush and AlMeraj, } \\
\text { 2019; de Oliveira et al., } \\
\text { 2016) }\end{array}$ \\
\hline 13 & $\begin{array}{l}\text { Keyboard inacces- } \\
\text { sible content }\end{array}$ & $\begin{array}{l}\text { Content not accessible by keyboard, such as } \\
\text { functionality or information. }\end{array}$ & $\begin{array}{l}\text { (Wentz et al., 2019; } \\
\text { Loureiro et al., 2014) }\end{array}$ \\
\hline 12 & $\begin{array}{l}\text { Insufficient con- } \\
\text { trast }\end{array}$ & Bad contrast ratio. & $\begin{array}{l}\text { (Wentz et al., 2019; } \\
\text { Gonçalves et al., 2018; } \\
\text { Galkute et al., 2020) }\end{array}$ \\
\hline 17 & $\begin{array}{l}\text { Inappropriate de- } \\
\text { scription in con- } \\
\text { trols }\end{array}$ & $\begin{array}{l}\text { Controls, such as a link or button, that have an } \\
\text { inappropriate description. }\end{array}$ & $\begin{array}{l}\text { (Rodrigues and Pri- } \\
\text { etch, 2018; Pribeanu } \\
\text { et al., 2014; Loureiro } \\
\text { et al., 2014; Doush and } \\
\text { AlMeraj, 2019) }\end{array}$ \\
\hline 23 & Useless elements & Elements that have no use. & (Gonçalves et al., 2018) \\
\hline 4 & $\begin{array}{l}\text { Too much infor- } \\
\text { mation }\end{array}$ & Pages that contain a lot of data and elements. & $\begin{array}{l}\text { (Pribeanu et al., 2014; } \\
\text { Doush and AlMeraj, } \\
2019 \text { ) }\end{array}$ \\
\hline 38 & $\begin{array}{l}\text { Inappropriate } \\
\text { feedback }\end{array}$ & $\begin{array}{l}\text { Feedback that is not identified by screen readers, } \\
\text { such as color-based information. }\end{array}$ & (Loureiro et al., 2014) \\
\hline 41 & Visible Focus & $\begin{array}{l}\text { The user cannot understand what the system } \\
\text { expects him to do }\end{array}$ & $\begin{array}{l}\text { (Doush and AlMeraj, } \\
\text { 2019) }\end{array}$ \\
\hline
\end{tabular}


Table 12 -Continued from previous page

\begin{tabular}{|c|c|c|c|}
\hline Barrier code & Barrier & Description & Studies - web \\
\hline 55 & Pause, Stop, Hide & $\begin{array}{l}\text { For information in motion, in intermittent mode, } \\
\text { in displacement or in automatic update, appro- } \\
\text { priate provisions are made. }\end{array}$ & $\begin{array}{l}\text { (Doush and AlMeraj, } \\
\text { 2019) }\end{array}$ \\
\hline 56 & $\begin{array}{l}\text { Audio description } \\
\text { or Alternative Me- } \\
\text { dia (Pre-recorded) }\end{array}$ & $\begin{array}{l}\text { Alternative to media-based or an audio descrip- } \\
\text { tion of pre-recorded video content, except when } \\
\text { the media is an alternative to text and is clearly } \\
\text { identified as such. }\end{array}$ & $\begin{array}{l}\text { (Doush and AlMeraj, } \\
\text { 2019) }\end{array}$ \\
\hline 57 & Analyze & $\begin{array}{l}\text { Elements with mark-up language follow mark- } \\
\text { up grammar. }\end{array}$ & $\begin{array}{l}\text { (Doush and AlMeraj, } \\
\text { 2019; Akram and Bt } \\
\text { Sulaiman, 2020) }\end{array}$ \\
\hline 49 & Use of colors & $\begin{array}{l}\text { Color is not used as the only visual means of } \\
\text { transmitting information, indicating an action, } \\
\text { asking for an answer or distinguishing a visual } \\
\text { element }\end{array}$ & $\begin{array}{l}\text { (Doush and AlMeraj, } \\
\text { 2019) }\end{array}$ \\
\hline 46 & $\begin{array}{l}\text { Error identifica- } \\
\text { tion }\end{array}$ & $\begin{array}{l}\text { If an input error is automatically detected, the } \\
\text { item with an error is identified and the error is } \\
\text { described to the user in text. }\end{array}$ & $\begin{array}{l}\text { (Doush and AlMeraj, } \\
\text { 2019) }\end{array}$ \\
\hline 8 & Language not set & Content that has no language defined. & $\begin{array}{l}\text { (Mátrai, 2018; Doush and } \\
\text { AlMeraj, 2019) }\end{array}$ \\
\hline 14 & $\begin{array}{l}\text { Incompatibility of } \\
\text { technologies }\end{array}$ & $\begin{array}{l}\text { Incompatible content with screen readers, such } \\
\text { as flash }\end{array}$ & (Aizpurua et al., 2015) \\
\hline 22 & $\begin{array}{l}\text { Unreachable help } \\
\text { link }\end{array}$ & Help link is not easy to find. & (Gonçalves et al., 2018) \\
\hline 28 & $\begin{array}{l}\text { Unexpected } \\
\text { changes }\end{array}$ & $\begin{array}{l}\text { Unexpected changes to pages that hide infor- } \\
\text { mation or erase data reported by the user. }\end{array}$ & $\begin{array}{l}\text { (Rodrigues and Prietch, } \\
\text { 2018) }\end{array}$ \\
\hline 16 & $\begin{array}{l}\text { Inadequate header } \\
\text { levels }\end{array}$ & $\begin{array}{l}\text { Sections or subsections that have an incorrect } \\
\text { level of headings. }\end{array}$ & $\begin{array}{l}\text { (Pribeanu et al., 2014; Va- } \\
\text { lencia et al., 2014) }\end{array}$ \\
\hline 39 & Keyboard & $\begin{array}{l}\text { All mouse operations have an accessible key- } \\
\text { board equivalents }\end{array}$ & (da Silva et al., 2018b) \\
\hline 37 & $\begin{array}{l}\text { Inconsistent con- } \\
\text { tent organization }\end{array}$ & Content that is not well organized. & (Pribeanu et al., 2014) \\
\hline 20 & $\begin{array}{l}\text { Inadequate navi- } \\
\text { gation sequence }\end{array}$ & $\begin{array}{l}\text { Content that does not allow an adequate navi- } \\
\text { gation sequence by screen readers. }\end{array}$ & $\begin{array}{l}\text { (Wentz et al., 2019; } \\
\text { Doush and AlMeraj, } \\
\text { 2019) }\end{array}$ \\
\hline 25 & $\begin{array}{l}\text { Inappropriate } \\
\text { terms }\end{array}$ & $\begin{array}{l}\text { Words that are not common or familiar to the } \\
\text { context of the content presented by a website. }\end{array}$ & (Loureiro et al., 2014) \\
\hline 31 & $\begin{array}{l}\text { Inappropriate al- } \\
\text { ternate text }\end{array}$ & $\begin{array}{l}\text { Alternative text in an image that does not cor- } \\
\text { rectly describe what it represents. }\end{array}$ & $\begin{array}{l}\text { (Aizpurua et al., 2015; } \\
\text { Loureiro et al., 2014) }\end{array}$ \\
\hline
\end{tabular}


Table 13. Accessibility problems encountered by expert inspections on mobile applications

\begin{tabular}{|c|c|c|c|}
\hline Barrier code & Barrier & Description & Studies - mobile \\
\hline 27 & $\begin{array}{l}\text { Absence of short- } \\
\text { cuts }\end{array}$ & Absence of shortcuts to access main content. & (de Oliveira et al., 2016) \\
\hline 5 & $\begin{array}{l}\text { Absence of head- } \\
\text { ers }\end{array}$ & $\begin{array}{l}\text { Pages that do not have headings to indicate main } \\
\text { content or sections. }\end{array}$ & (Carvalho et al., 2016) \\
\hline 18 & $\begin{array}{lr}\text { Absence } & \text { of } \\
\text { resources } & \text { for } \\
\text { expansion } & \end{array}$ & Absence of resources to expand textual content. & (de Oliveira et al., 2016) \\
\hline 1 & Absence of labels & Form fields that have no labels on their purpose. & $\begin{array}{l}\text { (de Oliveira et al., 2016; } \\
\text { Carvalho et al., 2016) }\end{array}$ \\
\hline 6 & $\begin{array}{l}\text { Absence of alter- } \\
\text { native text }\end{array}$ & $\begin{array}{l}\text { Non-text content that does not have alternative } \\
\text { text. }\end{array}$ & $\begin{array}{l}\text { (de Oliveira et al., 2016; } \\
\text { Carvalho et al., 2016) }\end{array}$ \\
\hline 15 & Absence of titles & Pages that do not have an identifying title. & (Carvalho et al., 2016) \\
\hline 12 & $\begin{array}{l}\text { Insufficient con- } \\
\text { trast }\end{array}$ & Bad contrast ratio. & $\begin{array}{l}\text { (de Oliveira et al., 2016; } \\
\text { Carvalho et al., 2016) }\end{array}$ \\
\hline 41 & Visible Focus & $\begin{array}{l}\text { The user cannot understand what the system } \\
\text { expects him to do. }\end{array}$ & $\begin{array}{l}\text { (de Oliveira et al., 2016; } \\
\text { Carvalho et al., 2016) }\end{array}$ \\
\hline 45 & $\begin{array}{l}\text { Consistent Identi- } \\
\text { fication }\end{array}$ & $\begin{array}{l}\text { Components that have the same functionality in } \\
\text { a set of web pages are identified consistently. }\end{array}$ & (de Oliveira et al., 2016) \\
\hline 48 & Images & $\begin{array}{l}\text { If the technologies being used can provide vi- } \\
\text { sual presentation, text is used to convey infor- } \\
\text { mation instead of images of text except for the } \\
\text { following. }\end{array}$ & (Carvalho et al., 2016) \\
\hline 46 & $\begin{array}{l}\text { Error identifica- } \\
\text { tion }\end{array}$ & $\begin{array}{l}\text { If an input error is automatically detected, the } \\
\text { item with an error is identified and the error is } \\
\text { described to the user in text. }\end{array}$ & (de Oliveira et al., 2016) \\
\hline 8 & Language not set & Content that has no language defined. & (Park et al., 2019) \\
\hline 42 & Location & $\begin{array}{l}\text { It is not possible to know where it is within the } \\
\text { system }\end{array}$ & (Carvalho et al., 2016) \\
\hline 59 & Time limits & $\begin{array}{l}\text { Users are advised of the duration of any user } \\
\text { inactivity that may cause data loss, unless data } \\
\text { is preserved when the user does not take any } \\
\text { action for more than } 20 \text { hours. }\end{array}$ & (Carvalho et al., 2016) \\
\hline 39 & Keyboard & $\begin{array}{l}\text { All mouse operations have an accessible key- } \\
\text { board equivalents }\end{array}$ & (Carvalho et al., 2016) \\
\hline 20 & $\begin{array}{l}\text { Inadequate navi- } \\
\text { gation sequence }\end{array}$ & $\begin{array}{l}\text { Content that does not allow an adequate navi- } \\
\text { gation sequence by screen readers. }\end{array}$ & $\begin{array}{l}\text { (de Oliveira et al., 2016; } \\
\text { Carvalho et al., 2016) }\end{array}$ \\
\hline
\end{tabular}


Table 14. Accessibility barriers encountered on websites by user evaluations

\begin{tabular}{|c|c|c|c|}
\hline Barrier code & Barrier & Description & Studies - web \\
\hline 1 & Absence of labels & Form fields that have no labels on their purpose. & $\begin{array}{l}\text { (Carvalho et al., 2018b; } \\
\text { Loureiro et al., 2015; } \\
\text { Power, 2018; Mátrai, } \\
\text { 2018; Abdolrahmani and } \\
\text { Kuber, 2016; Valencia } \\
\text { et al., 2014; Acosta- } \\
\text { Vargas et al., 2019b; Yi, } \\
\text { 2020) }\end{array}$ \\
\hline 2 & $\begin{array}{l}\text { Inappropriate link } \\
\text { destination }\end{array}$ & $\begin{array}{l}\text { Links that do not direct the user to the page they } \\
\text { are intended for. }\end{array}$ & $\begin{array}{l}\text { (Zitkus et al., 2016; Fer- } \\
\text { nandes et al., 2015) }\end{array}$ \\
\hline 3 & $\begin{array}{l}\text { Absence of con- } \\
\text { trast feature }\end{array}$ & $\begin{array}{l}\text { Absence of feature to increase contrast level } \\
\text { between text and page background. }\end{array}$ & (Zitkus et al., 2016) \\
\hline 4 & $\begin{array}{l}\text { Too much infor- } \\
\text { mation }\end{array}$ & Pages that contain a lot of data and elements. & $\begin{array}{l}\text { (Carvalho et al., 2018b; } \\
\text { Acosta-Vargas et al., } \\
\text { 2019b) }\end{array}$ \\
\hline 5 & $\begin{array}{l}\text { Absence of head- } \\
\text { ers }\end{array}$ & $\begin{array}{l}\text { Pages that do not have headings to indicate main } \\
\text { content or sections. }\end{array}$ & $\begin{array}{l}\text { (Power, 2018; Gonçalves } \\
\text { et al., 2018; Gadde and } \\
\text { Bolchini, 2014; Mátrai, } \\
\text { 2018; Archambault et al., } \\
\text { 2017; Acosta-Vargas } \\
\text { et al., 2019b; Akram and } \\
\text { Bt Sulaiman, 2020) }\end{array}$ \\
\hline 6 & $\begin{array}{l}\text { Absence of alter- } \\
\text { native text }\end{array}$ & $\begin{array}{l}\text { Non-text content that does not have alternative } \\
\text { text. }\end{array}$ & $\begin{array}{l}\text { (Carvalho et al., 2018b; } \\
\text { Loureiro et al., 2015; } \\
\text { Aizpurua et al., 2014; } \\
\text { Power, 2018; Nogueira } \\
\text { et al., 2017; Gonçalves } \\
\text { et al., 2018; Abdolrah- } \\
\text { mani and Kuber, 2016; } \\
\text { Yi, 2020; Valencia et al., } \\
\text { 2014; Akram and Bt Su- } \\
\text { laiman, 2020) }\end{array}$ \\
\hline 7 & Empty links & $\begin{array}{l}\text { Links that do not have a description of their } \\
\text { purpose. }\end{array}$ & $\begin{array}{l}\text { (Loureiro et al., 2015; } \\
\text { Fernandes et al., 2015; } \\
\text { Acosta-Vargas et al., } \\
\text { 2019b) }\end{array}$ \\
\hline 11 & $\begin{array}{l}\text { Absence of head- } \\
\text { ings in tables }\end{array}$ & $\begin{array}{l}\text { Tables that do not have identifier headings for } \\
\text { their elements in each cell. }\end{array}$ & $\begin{array}{l}\text { (Yi, 2020; Archambault } \\
\text { et al., 2017; Fernandes } \\
\text { et al., 2015) }\end{array}$ \\
\hline 12 & $\begin{array}{l}\text { Insufficient con- } \\
\text { trast }\end{array}$ & Bad contrast ratio. & $\begin{array}{l}\text { (Acosta-Vargas et al., } \\
\text { 2019b; Power, 2018) }\end{array}$ \\
\hline 13 & $\begin{array}{l}\text { Keyboard inacces- } \\
\text { sible content }\end{array}$ & $\begin{array}{l}\text { Content not accessible by keyboard, such as } \\
\text { functionality or information. }\end{array}$ & $\begin{array}{l}\text { (Loureiro et al., 2015; } \\
\text { Rodrigues and Prietch, } \\
\text { 2018; Valencia et al., } \\
\text { 2014; Akram and Bt Su- } \\
\text { laiman, 2020), }\end{array}$ \\
\hline 14 & $\begin{array}{l}\text { Incompatibility of } \\
\text { technologies }\end{array}$ & $\begin{array}{l}\text { Content inaccessible by screen readers, such as } \\
\text { flash }\end{array}$ & $\begin{array}{l}\text { (Carvalho et al., 2018b; } \\
\text { Loureiro et al., 2015; } \\
\text { Aizpurua et al., 2014; } \\
\text { Nogueira et al., 2017; } \\
\text { Aizpurua et al., 2015; Ab- } \\
\text { dolrahmani and Kuber, } \\
\text { 2016; Akram and Bt Su- } \\
\text { laiman, 2020) }\end{array}$ \\
\hline
\end{tabular}


Table 14 - Continued from previous page

\begin{tabular}{|c|c|c|c|}
\hline Barrier code & Barrier & Description & Studies - web \\
\hline 15 & Absence of titles & Pages that do not have an identifying title. & $\begin{array}{l}\text { (Aizpurua et al., 2014; } \\
\text { Gonçalves et al., 2018; } \\
\text { Mátrai, 2018) }\end{array}$ \\
\hline 16 & $\begin{array}{l}\text { Inadequate header } \\
\text { levels }\end{array}$ & $\begin{array}{l}\text { Sections or subsections that have an incorrect } \\
\text { level of headings. }\end{array}$ & $\begin{array}{l}\text { (Pereira and Archam- } \\
\text { bault, 2018; Gadde and } \\
\text { Bolchini, 2014) }\end{array}$ \\
\hline 17 & $\begin{array}{l}\text { Inappropriate de- } \\
\text { scription in con- } \\
\text { trols }\end{array}$ & $\begin{array}{l}\text { Controls, such as a link or button, that have an } \\
\text { inappropriate description. }\end{array}$ & $\begin{array}{l}\text { (Carvalho et al., 2018b; } \\
\text { Loureiro et al., 2015; } \\
\text { Pereira and Archambault, } \\
\text { 2018; Gonçalves et al., } \\
\text { 2018; Mátrai, 2018; } \\
\text { Aizpurua et al., 2015; Yi, } \\
\text { 2020) }\end{array}$ \\
\hline 18 & $\begin{array}{lr}\begin{array}{l}\text { Absence } \\
\text { resources } \\
\text { expansion }\end{array} & \text { for } \\
\end{array}$ & Absence of resources to expand textual content. & $\begin{array}{l}\text { (Zitkus et al., 2016; Fer- } \\
\text { nandes et al., 2015) }\end{array}$ \\
\hline 20 & $\begin{array}{l}\text { Inadequate navi- } \\
\text { gation sequence }\end{array}$ & $\begin{array}{l}\text { Content that does not allow an adequate navi- } \\
\text { gation sequence by screen readers. }\end{array}$ & $\begin{array}{l}\text { (Carvalho et al., 2018b; } \\
\text { Pereira and Archambault, } \\
\text { 2018; Yi, 2020; Valen- } \\
\text { cia et al., 2014; Acosta- } \\
\text { Vargas et al., 2019b) }\end{array}$ \\
\hline 22 & $\begin{array}{l}\text { Unreachable help } \\
\text { link }\end{array}$ & Help link is not easy to find. & $\begin{array}{l}\text { (Akram and Bt Sulaiman, } \\
2020 \text { ) }\end{array}$ \\
\hline 26 & $\begin{array}{l}\text { Absence of feed- } \\
\text { back }\end{array}$ & $\begin{array}{l}\text { When using any means of access, such as a link } \\
\text { or button, the user does not receive feedback. }\end{array}$ & $\begin{array}{l}\text { (Carvalho et al., 2018b; } \\
\text { Pereira and Archambault, } \\
\text { 2018; Loureiro et al., } \\
\text { 2015; Power, 2018; } \\
\text { Gonçalves et al., 2018; } \\
\text { Aizpurua et al., 2015; } \\
\text { Yi, 2020; Valencia et al., } \\
\text { 2014; Fernandes et al., } \\
\text { 2015; Archambault et al., } \\
\text { 2017) }\end{array}$ \\
\hline 27 & $\begin{array}{l}\text { Absence of short- } \\
\text { cuts }\end{array}$ & Absence of shortcuts to access main content. & $\begin{array}{l}\text { (Zitkus et al., 2016; } \\
\text { Gadde and Bolchini, } \\
\text { 2014; Yi, 2020) }\end{array}$ \\
\hline 28 & $\begin{array}{l}\text { Unexpected } \\
\text { changes }\end{array}$ & $\begin{array}{l}\text { Unexpected changes to pages that hide infor- } \\
\text { mation or erase data reported by the user. }\end{array}$ & (Power, 2018; Yi, 2020) \\
\hline 29 & $\begin{array}{l}\text { Unmet expecta- } \\
\text { tions }\end{array}$ & $\begin{array}{l}\text { When browsing a website, expectations about } \\
\text { content or function are not always met. }\end{array}$ & $\begin{array}{l}\text { (Carvalho et al., 2018b; } \\
\text { Aizpurua et al., 2015) }\end{array}$ \\
\hline 31 & $\begin{array}{l}\text { Inappropriate al- } \\
\text { ternate text }\end{array}$ & $\begin{array}{l}\text { Alternative text in an image that does not cor- } \\
\text { rectly describe what it represents. }\end{array}$ & $\begin{array}{l}\text { Loureiro et al. (2015); } \\
\text { Gonçalves et al. (2018); } \\
\text { Mátrai (2018); Aizpurua } \\
\text { et al. (2015); Abdolrah- } \\
\text { mani and Kuber (2016); } \\
\text { Yi (2020) }\end{array}$ \\
\hline 32 & $\begin{array}{l}\text { Inappropriate tex- } \\
\text { tual content }\end{array}$ & $\begin{array}{l}\text { Lists, paragraphs or other textual elements that } \\
\text { are not correctly identified by screen readers. }\end{array}$ & $\begin{array}{l}\text { Mátrai (2018); Archam- } \\
\text { bault et al. (2017); } \\
\text { da Silva et al. (2016b); } \\
\text { Fernandes et al. (2015) }\end{array}$ \\
\hline 33 & $\begin{array}{l}\text { Inadequate writ- } \\
\text { ing }\end{array}$ & Grammatical or typing errors in textual content. & $\begin{array}{l}\text { (Gonçalves et al., 2018; } \\
\text { Abdolrahmani and Kuber, } \\
\text { 2016) }\end{array}$ \\
\hline 34 & Inappropriate title & $\begin{array}{l}\text { Page title that does not correctly describe the } \\
\text { content. }\end{array}$ & $\begin{array}{l}\text { (Loureiro et al., 2015; } \\
\text { Gonçalves et al., 2018; } \\
\text { Yi, 2020) }\end{array}$ \\
\hline
\end{tabular}


Table 14 -Continued from previous page

\begin{tabular}{|c|c|c|c|}
\hline Barrier code & Barrier & Description & Studies - web \\
\hline 35 & $\begin{array}{l}\text { Inappropriate } \\
\text { alternative to } \\
\text { Captcha }\end{array}$ & Alternative audio in another language. & $(\mathrm{Yi}, 2020)$ \\
\hline 36 & $\begin{array}{l}\text { Inappropriate de- } \\
\text { scription in head- } \\
\text { ers }\end{array}$ & $\begin{array}{l}\text { Headers that do not have a proper description } \\
\text { of the content they are linked to. }\end{array}$ & $\begin{array}{l}\text { (Gonçalves et al., 2018; } \\
\text { Fernandes et al., 2015) }\end{array}$ \\
\hline 37 & $\begin{array}{l}\text { Inconsistent con- } \\
\text { tent organization }\end{array}$ & Content that is not well organized. & (Carvalho et al., 2018b) \\
\hline 38 & $\begin{array}{l}\text { Inappropriate } \\
\text { feedback }\end{array}$ & $\begin{array}{l}\text { Feedback that is not identified by screen readers, } \\
\text { such as color-based information. }\end{array}$ & (Loureiro et al., 2015) \\
\hline 39 & Keyboard & $\begin{array}{l}\text { mouse operations have an accessible keyboard } \\
\text { equivalents }\end{array}$ & $\begin{array}{l}\text { (Valencia et al., 2014; } \\
\text { Acosta-Vargas et al., } \\
\text { 2019b; Akram and Bt } \\
\text { Sulaiman, 2020) }\end{array}$ \\
\hline 46 & $\begin{array}{l}\text { Error identifica- } \\
\text { tion }\end{array}$ & $\begin{array}{l}\text { If an input error is automatically detected, the } \\
\text { item with an error is identified and the error is } \\
\text { described to the user in text. }\end{array}$ & $\begin{array}{l}\text { (Acosta-Vargas et al., } \\
2019 b)\end{array}$ \\
\hline 48 & Images & $\begin{array}{l}\text { If the technologies being used can provide vi- } \\
\text { sual presentation, text is used to convey infor- } \\
\text { mation instead of images of text except for the } \\
\text { following: }\end{array}$ & $\begin{array}{l}\text { (Acosta-Vargas et al., } \\
2019 b)\end{array}$ \\
\hline 49 & Use of colors & $\begin{array}{l}\text { Color is not used as the only visual means of } \\
\text { transmitting information, indicating an action, } \\
\text { asking for an answer or distinguishing a visual } \\
\text { element }\end{array}$ & $\begin{array}{l}\text { (Acosta-Vargas et al., } \\
2019 b)\end{array}$ \\
\hline 50 & Resize text & Increase text & $\begin{array}{l}\text { (Acosta-Vargas et al., } \\
2019 \mathrm{c})\end{array}$ \\
\hline 51 & Spacing & spacing between images, text, forms & $\begin{array}{l}\text { (Acosta-Vargas et al., } \\
\text { 2019b) }\end{array}$ \\
\hline 52 & $\begin{array}{l}\text { Overlapping win- } \\
\text { dows }\end{array}$ & superimpose windows & $\begin{array}{l}\text { (Acosta-Vargas et al., } \\
\text { 2019b) }\end{array}$ \\
\hline 53 & Browser Control & there is no control & $\begin{array}{l}\text { (Acosta-Vargas et al., } \\
\text { 2019b) }\end{array}$ \\
\hline 54 & Interruptions & $\begin{array}{l}\text { Interruptions can be postponed or suppressed } \\
\text { by the user, except for interruptions that involve } \\
\text { an emergency. }\end{array}$ & $\begin{array}{l}\text { (Acosta-Vargas et al., } \\
\text { 2019b) }\end{array}$ \\
\hline 55 & Pause, Stop, Hide & $\begin{array}{l}\text { For information in motion, in intermittent mode, } \\
\text { in displacement or in automatic update, all the } \\
\text { following statements are green }\end{array}$ & $\begin{array}{l}\text { (Acosta-Vargas et al., } \\
\text { 2019b; Akram and Bt } \\
\text { Sulaiman, 2020) }\end{array}$ \\
\hline
\end{tabular}


Table 15. Accessibility barriers encountered on mobile apps by user evaluations

\begin{tabular}{|c|c|c|c|}
\hline Barrier code & Barrier & Description & Studies - mobile \\
\hline 1 & Absence of labels & Form fields that have no labels on their purpose. & $\begin{array}{l}\text { (Carvalho et al., 2018b; } \\
\text { Acosta-Vargas et al., } \\
2020)\end{array}$ \\
\hline 2 & $\begin{array}{l}\text { Inappropriate link } \\
\text { destination }\end{array}$ & $\begin{array}{l}\text { Links that do not direct the user to the page they } \\
\text { are intended for. }\end{array}$ & (Fernandes et al., 2015) \\
\hline 4 & $\begin{array}{l}\text { Too much infor- } \\
\text { mation }\end{array}$ & Pages that contain a lot of data and elements. & $\begin{array}{l}\text { (Carvalho et al., 2018b; } \\
\text { Park et al., 2019) }\end{array}$ \\
\hline 6 & $\begin{array}{l}\text { Absence of alter- } \\
\text { native text }\end{array}$ & $\begin{array}{l}\text { Non-text content that does not have alternative } \\
\text { text. }\end{array}$ & $\begin{array}{l}\text { (Carvalho et al., 2018b; } \\
\text { da Silva et al., 2016b; } \\
\text { Acosta-Vargas et al., } \\
\text { 2019a; Park et al., 2019; } \\
\text { da Silva et al., 2018b) }\end{array}$ \\
\hline 7 & Empty links & $\begin{array}{l}\text { Links that do not have a description of their } \\
\text { purpose. }\end{array}$ & (da Silva et al., 2016b) \\
\hline 8 & Language not set & Content that has no language defined. & $\begin{array}{l}\text { (da Silva et al., 2018b; } \\
\text { Kulpa and Amaral, 2014) }\end{array}$ \\
\hline 12 & $\begin{array}{l}\text { Insufficient con- } \\
\text { trast }\end{array}$ & Bad contrast ratio. & $\begin{array}{l}\text { (Kim et al., 2016; } \\
\text { da Silva et al., 2018b; } \\
\text { Kulpa and Amaral, 2014; } \\
\text { Acosta-Vargas et al., } \\
\text { 2020, 2019a; da Silva } \\
\text { et al., 2016b) }\end{array}$ \\
\hline 14 & $\begin{array}{l}\text { Incompatibility of } \\
\text { technologies }\end{array}$ & $\begin{array}{l}\text { Content inaccessible by screen readers, such as } \\
\text { flash. }\end{array}$ & (Carvalho et al., 2018b) \\
\hline 15 & Absence of titles & Pages that do not have an identifying title. & $\begin{array}{l}\text { (da Silva et al., 2016b, } \\
\text { 2018b) }\end{array}$ \\
\hline 17 & $\begin{array}{l}\text { Inappropriate de- } \\
\text { scription in con- } \\
\text { trols }\end{array}$ & $\begin{array}{l}\text { Controls, such as a link or button, that have an } \\
\text { inappropriate description. }\end{array}$ & $\begin{array}{l}\text { (Carvalho et al., 2018b; } \\
\text { Acosta-Vargas et al., } \\
2020)\end{array}$ \\
\hline 18 & $\begin{array}{lr}\text { Absence } & \text { of } \\
\text { resources } & \text { for } \\
\text { expansion } & \end{array}$ & Absence of resources to expand textual content. & (Fernandes et al., 2015) \\
\hline 20 & $\begin{array}{l}\text { Inadequate navi- } \\
\text { gation sequence }\end{array}$ & $\begin{array}{l}\text { Content that does not allow an adequate navi- } \\
\text { gation sequence by screen readers. }\end{array}$ & $\begin{array}{l}\text { (Carvalho et al., 2018b; } \\
\text { da Silva et al., 2016b; } \\
\text { Acosta-Vargas et al., } \\
\text { 2019a; da Silva et al., } \\
\text { 2018b; Kulpa and Ama- } \\
\text { ral, 2014) }\end{array}$ \\
\hline 22 & $\begin{array}{l}\text { Unreachable help } \\
\text { link }\end{array}$ & Help link is not easy to find. & (da Silva et al., 2016b) \\
\hline 26 & $\begin{array}{l}\text { Absence of feed- } \\
\text { back }\end{array}$ & $\begin{array}{l}\text { When using any means of access, such as a link } \\
\text { or button, the user does not receive feedback. }\end{array}$ & $\begin{array}{l}\text { (Carvalho et al., 2018b; } \\
\text { da Silva et al., 2016b) }\end{array}$ \\
\hline 32 & $\begin{array}{l}\text { Inappropriate tex- } \\
\text { tual content }\end{array}$ & $\begin{array}{l}\text { Lists, paragraphs or other textual elements that } \\
\text { are not correctly identified by screen readers. }\end{array}$ & (da Silva et al., 2016b) \\
\hline 34 & Inappropriate title & $\begin{array}{l}\text { Page title that does not correctly describe the } \\
\text { content. }\end{array}$ & (Kim et al., 2016) \\
\hline 37 & $\begin{array}{l}\text { Inconsistent con- } \\
\text { tent organization }\end{array}$ & Content that is not well organized. & (Carvalho et al., 2018b) \\
\hline 39 & Keyboard & $\begin{array}{l}\text { All mouse operations have an accessible key- } \\
\text { board equivalents }\end{array}$ & $\begin{array}{l}\text { (Kim et al., 2016; } \\
\text { da Silva et al., 2016b; } \\
\text { Akram and Bt Sulaiman, } \\
2020 \text { ) }\end{array}$ \\
\hline 40 & Violated header & Violated header structures. & (Park et al., 2019) \\
\hline 41 & Visible Focus & $\begin{array}{l}\text { The user cannot understand what the system } \\
\text { expects him to do. }\end{array}$ & $\begin{array}{l}\text { (da Silva et al., 2016b; } \\
\text { Park et al., 2019) }\end{array}$ \\
\hline
\end{tabular}


Table 15 - Continued from previous page

\begin{tabular}{|c|c|c|c|}
\hline Barrier code & Barrier & Description & Studies - mobile \\
\hline 42 & Location & $\begin{array}{l}\text { It is not possible to know where it is within the } \\
\text { system }\end{array}$ & $\begin{array}{l}\text { (da Silva et al., 2016b; } \\
\text { Kim et al., 2016) }\end{array}$ \\
\hline 43 & $\begin{array}{l}\text { Change upon re- } \\
\text { quest }\end{array}$ & Can’t see pop-up. & (da Silva et al., 2016b) \\
\hline 47 & Order Focus & $\begin{array}{l}\text { If a web page can be navigated sequentially and } \\
\text { the navigation sequences affect the meaning or } \\
\text { the operation, the components that can be fo- } \\
\text { cused are focused on in an order that preserves } \\
\text { meaning and operability }\end{array}$ & (Park et al., 2019) \\
\hline 48 & Images & $\begin{array}{l}\text { If the technologies being used can provide vi- } \\
\text { sual presentation, text is used to convey infor- } \\
\text { mation instead of images of text except for the } \\
\text { following. }\end{array}$ & $\begin{array}{l}\text { (Acosta-Vargas et al., } \\
\text { 2019a) }\end{array}$ \\
\hline 49 & Use of colors & $\begin{array}{l}\text { Color is not used as the only visual means of } \\
\text { transmitting information, indicating an action, } \\
\text { asking for an answer or distinguishing a visual } \\
\text { element }\end{array}$ & $\begin{array}{l}\text { Acosta-Vargas et al. } \\
(2019 a)\end{array}$ \\
\hline 50 & Resize text & Increase text & $\begin{array}{l}\text { (Kim et al., 2016; Acosta- } \\
\text { Vargas et al., 2020) }\end{array}$ \\
\hline 51 & Spacing & spacing between images, text, forms. & (Kim et al., 2016) \\
\hline 55 & Pause, Stop, Hide & $\begin{array}{l}\text { For information in motion, in intermittent mode, } \\
\text { in displacement or in automatic update, all the } \\
\text { following statements are green. }\end{array}$ & (Kim et al., 2016) \\
\hline 56 & $\begin{array}{l}\text { Audio description } \\
\text { or Alternative Me- } \\
\text { dia (Pre-recorded) }\end{array}$ & $\begin{array}{l}\text { An alternative to media based or an audio de- } \\
\text { scription of pre-recorded video content is pro- } \\
\text { vided for synchronized media, except when the } \\
\text { media is an alternative to text and is clearly } \\
\text { identified as such. }\end{array}$ & (Park et al., 2019) \\
\hline 57 & Analyze & $\begin{array}{l}\text { In content implemented using markup lan- } \\
\text { guages, the elements have complete start and } \\
\text { end tags, the elements are nested according to } \\
\text { the respective specifications, the elements do } \\
\text { not contain duplicate attributes, and any IDs are } \\
\text { unique, except when the specifications allow } \\
\text { these characteristics. }\end{array}$ & (Park et al., 2019) \\
\hline 58 & $\begin{array}{l}\text { Visual Presenta- } \\
\text { tion }\end{array}$ & $\begin{array}{l}\text { Foreground and background colors can be se- } \\
\text { lected by the user. }\end{array}$ & (da Silva et al., 2018b) \\
\hline 60 & $\begin{array}{l}\text { Difficulty using } \\
\text { horizontal mode }\end{array}$ & - & (Kim et al., 2016) \\
\hline 61 & $\begin{array}{l}\text { Difficulty finding } \\
\text { the menu }\end{array}$ & - & (Kim et al., 2016) \\
\hline 62 & Speak very slow. & - & (Kim et al., 2016) \\
\hline 63 & $\begin{array}{l}\text { Face recognition } \\
\text { performance } \\
\text { is lower than I } \\
\text { expected. }\end{array}$ & - & (Kim et al., 2016) \\
\hline 64 & $\begin{array}{l}\text { Recording the } \\
\text { TalkBack sound } \\
\text { with my voice. }\end{array}$ & - & (Kim et al., 2016) \\
\hline 65 & $\begin{array}{l}\text { Difficulties to un- } \\
\text { derstand the loca- } \\
\text { tion of a face on } \\
\text { the screen. }\end{array}$ & - & (Kim et al., 2016) \\
\hline 66 & $\begin{array}{l}\text { Correct pronunci- } \\
\text { ation. }\end{array}$ & - & (Kim et al., 2016) \\
\hline 67 & Target Size & Font size, button. & (Kim et al., 2016) \\
\hline
\end{tabular}


Table 15 - Continued from previous page

\begin{tabular}{|c|c|c|c|}
\hline Barrier code & Barrier & Description & Studies - mobile \\
\hline 68 & $\begin{array}{l}\text { Hostile voice } \\
\text { screen reader. }\end{array}$ & - & (Kim et al., 2016) \\
\hline 69 & $\begin{array}{l}\text { The beep sound } \\
\text { lasts a long time. }\end{array}$ & - & (Kim et al., 2016) \\
\hline 70 & $\begin{array}{l}\text { Difficulties in } \\
\text { memorizing the } \\
\text { interface layout. }\end{array}$ & - & (Kim et al., 2016) \\
\hline 71 & $\begin{array}{l}\text { Difficulty under- } \\
\text { standing the direc- } \\
\text { tion to move the } \\
\text { camera. }\end{array}$ & - & (Kim et al., 2016) \\
\hline 72 & $\begin{array}{l}\text { Difficulties to in- } \\
\text { fer the word of } \\
\text { the big and small } \\
\text { face. }\end{array}$ & - & (Kim et al., 2016) \\
\hline 73 & Speak very loudly & - & (Kim et al., 2016) \\
\hline 74 & $\begin{array}{l}\text { Difficulty using a } \\
\text { touch-sensitive in- } \\
\text { terface }\end{array}$ & - & (Kim et al., 2016) \\
\hline 75 & Source shape & - & (Kim et al., 2016) \\
\hline 76 & $\begin{array}{l}\text { Difficulties in } \\
\text { recognizing the } \\
\text { meaning of icon } \\
\text { designs }\end{array}$ & - & (Kim et al., 2016) \\
\hline 77 & $\begin{array}{l}\text { Complex inter- } \\
\text { face layout }\end{array}$ & - & (Kim et al., 2016) \\
\hline 78 & $\begin{array}{l}\text { Very loud beep } \\
\text { sound }\end{array}$ & - & (Kim et al., 2016) \\
\hline 79 & Stroke width & - & (Kim et al., 2016) \\
\hline 80 & $\begin{array}{l}\text { Needs higher } \\
\text { recording quality }\end{array}$ & - & (Kim et al., 2016) \\
\hline
\end{tabular}

